\title{
Vertical distribution of ozone and VOCs in the low boundary layer of Mexico City
}

\author{
E. Velasco ${ }^{1,2}$, C. Márquez $^{3}$, E. Bueno ${ }^{3}$, R. M. Bernabé ${ }^{3}$, A. Sánchez ${ }^{3}$, O. Fentanes ${ }^{3}$, H. Wöhrnschimmel ${ }^{3}$, \\ B. Cárdenas ${ }^{3}$, A. Kamilla ${ }^{4}$, S. Wakamatsu ${ }^{4,5}$, and L. T. Molina ${ }^{1,2}$ \\ ${ }^{1}$ Molina Center for Energy and the Environment (MCE2), La Jolla, CA, USA \\ ${ }^{2}$ Department of Earth, Atmospheric and Planetary Sciences, Massachusetts Institute of Technology, Cambridge, MA, USA \\ ${ }^{3}$ Centro Nacional de Investigación y Capacitación Ambiental del Inst. Nacional de Ecología (CENICA-INE), D.F., Mexico \\ ${ }^{4}$ Japanese International Cooperation Agency (JICA), Tokyo, Japan \\ ${ }^{5}$ Atmospheric Environmental Science Laboratory, Faculty of Agriculture, Ehime University, Ehime, Japan
}

Received: 30 July 2007 - Published in Atmos. Chem. Phys. Discuss.: 30 August 2007

Revised: 24 April 2008 - Accepted: 20 May 2008 - Published: 20 June 2008

\begin{abstract}
The evolution of ozone $\left(\mathrm{O}_{3}\right)$ and 13 volatile organic compounds (VOCs) in the boundary layer of Mexico City was investigated during 2000-2004 to improve our understanding of the complex interactions between those trace gases and meteorological variables, and their influence on the air quality of a polluted megacity. A tethered balloon, fitted with electrochemical and meteorological sondes, was used to obtain detailed vertical profiles of $\mathrm{O}_{3}$ and meteorological parameters up to $1000 \mathrm{~m}$ above ground during part of the diurnal cycle (02:00-18:00 h). VOCs samples were collected up to $200 \mathrm{~m}$ by pumping air to canisters with a Teflon tube attached to the tether line. Overall, features of these profiles were found to be consistent with the formation of an upper residual layer during nighttime carrying over a fraction of the $\mathrm{O}_{3}$ from the previous day that contributes to the background concentration in surrounding regions. At the same time the release of heat stored in the urban surface forms a shallow unstable layer close to the ground, where the nocturnal emissions are trapped. After sunrise an $\mathrm{O}_{3}$ balance is determined by photochemical production, entrainment from the upper residual layer and destruction by titration with nitric oxide, delaying the ground-level $\mathrm{O}_{3}$ rise by $2 \mathrm{~h}$. The subsequent evolution of the conductive boundary layer and vertical distribution of pollutants are discussed in terms of the energy balance, the presence of turbulence and the atmospheric stability.
\end{abstract}

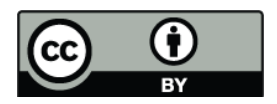

Correspondence to: E. Velasco (evelasco@mce2.org)

\section{Introduction}

Air overlying a region has layers of diverse history and consequently diverse composition and chemistry, as well as complex vertical distributions of pollutants. These vertical distributions are result of the horizontal and vertical transport due to the effects of the winds and turbulence produced by thermal fluxes and surface friction. In practice, vertical profiles of pollutants are estimated by mathematical models. The drawback of these models is that they require ideal conditions; otherwise their predictions are more uncertain. In an urban area there are many buildings, which cause large inhomogeneities in the energy and wind profiles, and thus the vertical distributions of pollutants are difficult to model. A clear understanding of the evolution of air pollutants at different heights of the boundary layer over urban areas is an important factor to improve the air quality assessment of polluted cities, where the high concentrations of ozone $\left(\mathrm{O}_{3}\right)$ and other toxic pollutants produce serious impacts on public health. For example, the characterization of nighttime accumulation of pollutants in the lowest layers and their subsequent interactions in the following morning as the nocturnal boundary layer begins to break up are necessary to evaluate the effectiveness of pollution control measures, such as limiting stationary emissions and extending vehicular traffic restrictions at night, as well as instituting a later workday to shift the morning rush hour to later on after sunrise.

Despite the importance of the vertical distribution of pollutants in urban areas, data to characterize the lowest few hundred meters of the atmosphere are scarce, and the complex interactions between anthropogenic emissions and the evolving chemistry of secondary pollutants in the urban boundary

Published by Copernicus Publications on behalf of the European Geosciences Union. 
layer are not yet well understood. This lack of information is accentuated in urban areas located in tropical and subtropical regions, where much of the urban population growth occurs. A good example of these urban centers is Mexico City, the second largest megacity and one of the most polluted urban areas of the world. Mexico City has a population of 19 millions, around 4 million vehicles and over 50000 industries. It is situated in the Valley of Mexico, at a low latitude $\left(19^{\circ} 25^{\prime} \mathrm{N}\right)$ and at high altitude $(2240 \mathrm{~m})$, resulting in subtropical weather and intense solar radiation. In addition, the elevated anthropogenic emissions and the area's topography with mountains to the west, east and south of the valley produce high levels of photochemical pollutants daily (Molina and Molina, 2002). These characteristics have converted Mexico City into an ideal laboratory to perform field experiments to address the urban air pollution of the developing world.

A number of extensive field campaigns have included upper layer measurements in Mexico City. The Mexico City Air Quality Research Initiative (MARI) included upper air quality measurements using tethered balloons, rawinsondes, a lidar and an aircraft during the winter of 1991 (Streit and Guzman, 1996; Nickerson et al., 1992). During the takeoffs and landings of the aircraft, vertical profiles of $\mathrm{O}_{3}$, nitrogen oxides $\left(\mathrm{NO}_{\mathrm{x}}\right)$, carbon monoxide $(\mathrm{CO})$ and aerosols were acquired (Pérez-Vidal and Raga, 1998). The IMADAAVER (Investigación sobre Materia Particulada y Deterioro Atmosférico, Aerosol and Visibility Evaluation Research) experiment in February and March of 1997 included diverse meteorological measurements to characterize the wind circulation and boundary layer of the Valley of Mexico (Doran et al., 1998). From 2000 to 2004 the National Center for Environmental Research and Training (CENICA) of the National Institute of Ecology (INE) of Mexico, with the support of the Japanese International Cooperation Agency (JICA), conducted tethered balloon measurements during selected days to improve understanding of the vertical evolution of pollutants in the boundary layer of Mexico City. Measurements corresponding to 2002 and 2003 were part of the MCMA-2002 \& 2003 field campaigns (Molina et al., 2007). Wöhrnschimmel et al. (2006) analyzed the 2003 measurements in terms of the impact of emission sources on the vertical profiles of pollutants. The recent MILAGRO (Megacitiy Initiative: Local and Global Research Observations) field campaign in Mexico City during March 2006 included a wide array of instruments located at ground sites and onboard aircraft to study the evolution of emissions from a megacity (see http://mce2.org).

This manuscript analyzes data obtained from tethered balloon measurements during 2000 to 2004 . These measurements included vertical distributions of $\mathrm{O}_{3}$ and meteorology up to $1000 \mathrm{~m}$ above ground level (all heights hereafter are referenced to ground level), and for the first time, observations of the concentrations of 13 selected VOCs (ethane, propane, propylene, butane, acetylene, pentane, hexane, hep- tane, benzene, octane, toluene, nonane and o-xylene) in the lowest $200 \mathrm{~m}$ of the atmosphere of Mexico City. These VOCs were selected because they are representative species of the VOC burden in the atmosphere of Mexico City (Velasco et al., 2007). They included alkanes, alkenes, alkynes and aromatic species. The objectives of this study were three-folds: 1) to investigate the diurnal vertical distribution and concentrations of $\mathrm{O}_{3}$ and VOCs in the urban boundary layer of a polluted megacity; 2 ) to determine the diurnal variations of these pollutants in terms of the evolution of the convective boundary layer; and 3) to provide vertical profiles as input data for air quality models.

Despite the particular characteristics of air pollution and meteorology of Mexico City, some features of the evolution of the boundary layer and vertical distribution of pollutants discussed in this article have been observed also in other places of the world using tethered balloons (e.g., Lee et al., 2003; Glaser et al., 2003; Baumbach and Vogt, 2003; Chen et al., 2002; Aneja et al., 2000). The results presented here are expected to provide valuable insight to other polluted urban areas of the world, particularly for less developed regions located at low latitudes and high altitudes with similar problems of anthropogenic emissions from outdated industrial operations and large vehicle fleets.

\section{Experiment description}

A total of 175 vertical profiles of $\mathrm{O}_{3}$ and meteorology were measured by a medium-sized tethered balloon (Vaisala TSB9) over 28 selected days between 2000 and $2004^{1}$. The number of profiles during one day of measurements varied from 2 to 11 , depending on the aeronautical activity over the city and the wind intensity (the balloon was never launched when the surface wind exceeded $5 \mathrm{~m} \mathrm{~s}^{-1}$ and always descended at any height when the wind reached $10 \mathrm{~m} \mathrm{~s}^{-1}$ ). In addition, the wind conditions did not always allow the balloon to reach the desired altitude, mostly in the afternoons, when wind speed increased and the balloon's control became complicated. 101 profiles were obtained over an altitude of $500 \mathrm{~m}$ with $40 \%$ reaching more than $950 \mathrm{~m}$. A third of all profiles included speciation of the 13 VOC species mentioned above up to $200 \mathrm{~m}$. Figure 1 shows the number of profiles measured throughout the investigated part of the diurnal cycle divided by hours and three categories according to their maximum height and whether they included VOC sampling. Almost all profiles were measured during the dry-warm season from March to May and the dry-cold season from November to February of Mexico City, when convective processes are not as strong and the pollutants accumulate in the boundary layer. During the rainy season (from June to October), it is difficult

\footnotetext{
${ }^{1}$ A table listing the locations, dates, times and heights for each profile is available online with this article as supplementary material.
} 


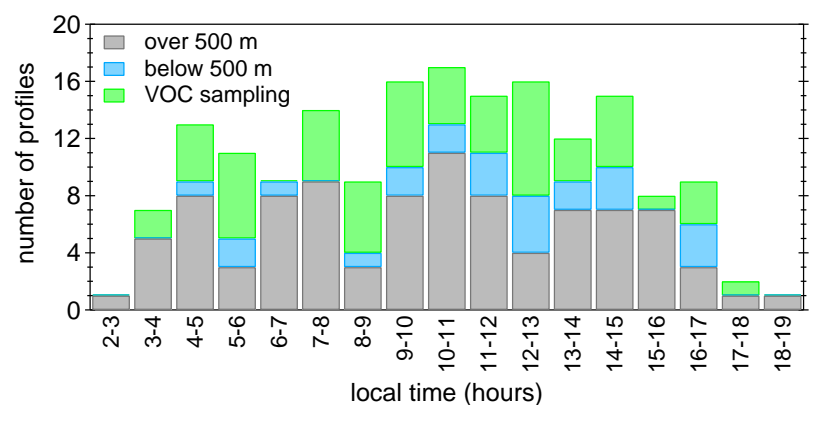

Fig. 1. Number of profiles measured throughout the investigated part of the diurnal cycle. Profiles from the three launching sites are included.

to launch the balloon; the pollutants are more efficiently removed from the boundary layer by wet deposition or simply by the strong vertical motions generated by the convective storms. The results presented here include profiles measured during February 2002 and April 2003 as part of the MCMA2002/2003 field campaigns (Molina et al., 2007).

The tethered balloon was launched at 3 different sites within the urban core of Mexico City: 1) The CENICA site located at the southeast part of the city (W $99^{\circ} 04^{\prime} 25^{\prime \prime}$, $\mathrm{N} 19^{\circ} 21^{\prime} 31.8^{\prime \prime}$ ) in a mixed area surrounded by residences, small and medium industries, services and commerce. The traffic was heavy and composed of old and new vehicles; old vehicles usually do not have catalytic converter and use carburetors, in contrast to new vehicles that have catalytic converters and use modern emission control technologies. About $88 \%$ of the profiles were obtained at this site; they were measured from 02:00 to 19:00 h local time (all times hereafter are referenced to local time). 2) The sport facilities of the National Polytechnic Institute (IPN) located at the northwest part of the city (W $\left.99^{\circ} 08^{\prime} 19.8^{\prime \prime}, \mathrm{N} 19^{\circ} 29^{\prime} 52.9^{\prime \prime}\right)$; 3) the practice stadium of the National Autonomous University of Mexico (UNAM) located at the southwest (W 99 $11^{\prime} 13.1^{\prime \prime}$, $\mathrm{N} 19^{\circ} 19^{\prime} 40^{\prime \prime}$ ). Measurements at IPN and UNAM were restricted from 09:00 to 16:00 h, and frequently the maximum elevation was limited to $500 \mathrm{~m}$. It is important to point out that the Mexico City airport is located at the center of the city; it was necessary to coordinate the tethered balloon flights with the airport authorities to avoid interference with the airplanes' flight paths. Hence only a few profiles were measured at IPN and UNAM: 10 and 13 profiles, respectively. A comparison of these profiles with those measured at the CENICA site showed that the magnitude, and the vertical and diurnal patterns are similar.

Meteorological parameters, including ambient temperature, atmospheric pressure, relative humidity, and wind speed and direction, were measured by a meteorological sonde (TS5A-SP Tethersonde) tethered $10 \mathrm{~m}$ below the balloon. The data collected by the sonde were sent to ground by a radio transmitter. The height of the balloon was controlled by com-

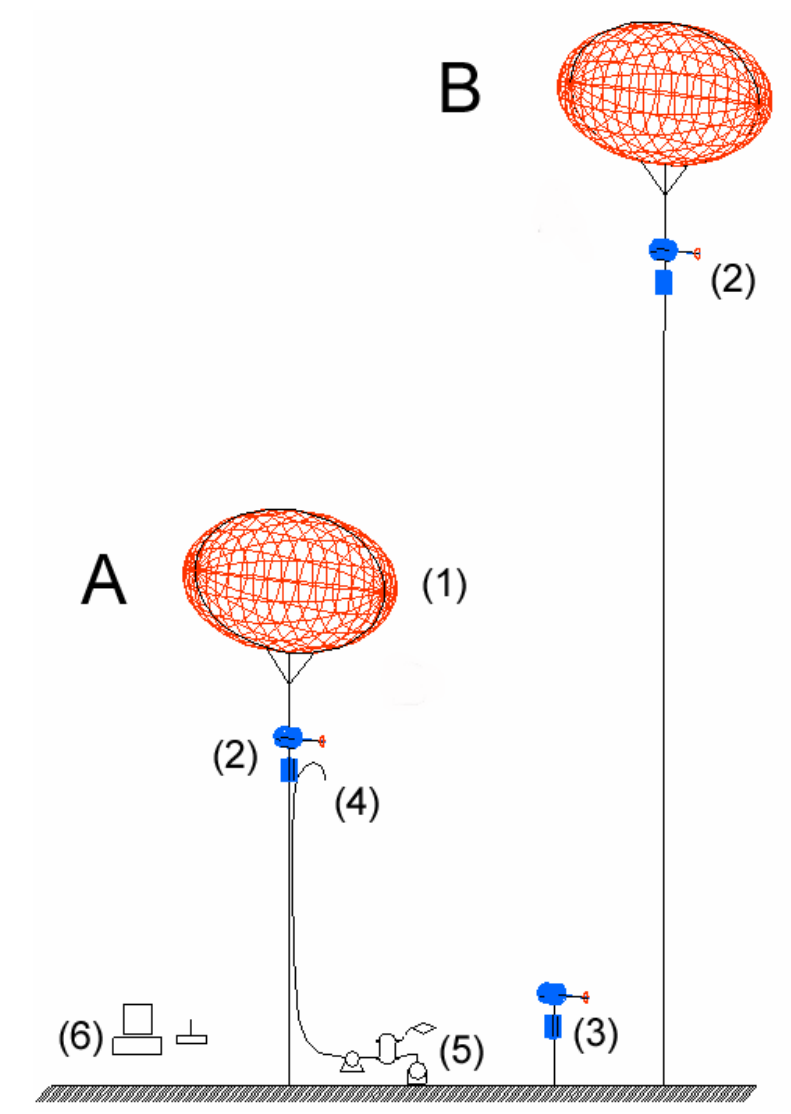

Fig. 2. Set up of the tethered balloon system. (A) Vertical profile measurements of VOCs, $\mathrm{O}_{3}$ and meteorology up to $200 \mathrm{~m}$. (B) Vertical profile measurements of $\mathrm{O}_{3}$ and meteorology up to $1000 \mathrm{~m}$. The tethered balloon system is composed of: (1) $9 \mathrm{~m}^{3}$ balloon filled with helium, (2) meteorological sonde with the $\mathrm{O}_{3}$ electrochemical cell below the balloon, (3) meteorological sonde at ground level, (4) Teflon tube, (5) diaphragm pump and stainless-steel canister for the VOCs sampling, and (6) ratio receiver system.

paring atmospheric pressure readings from the sonde located next to the balloon to readings from the second sonde located at ground level (see Fig. 2). $\mathrm{O}_{3}$ concentrations were measured by an electrochemical sonde (4Z ECC-O3-Sonde) tethered together with the meteorological sonde $10 \mathrm{~m}$ below the balloon.

Electrochemical sondes rely on the conversion of chemicals in a solution by ambient $\mathrm{O}_{3}$ to alter the electric conductivity of the solution (Parrish and Fehsenfeld, 2000). These sondes are very light and have been widely used to measure $\mathrm{O}_{3}$ profiles in the atmosphere. However, the measurements made by these sondes may suffer interferences from compounds other than $\mathrm{O}_{3}$, such as sulfur dioxide $\left(\mathrm{SO}_{2}\right)$, nitrogen dioxide $\left(\mathrm{NO}_{2}\right)$ and peroxyacetylnitrate (PAN) (Barnes et al., 1985; Grant and Wong, 1999) that contribute to the measurement uncertainty. Barnes et al. (1985) estimated these uncertainties to be between 6 and 10\% from background current. For each day of measurements, the electrochemical sondes 


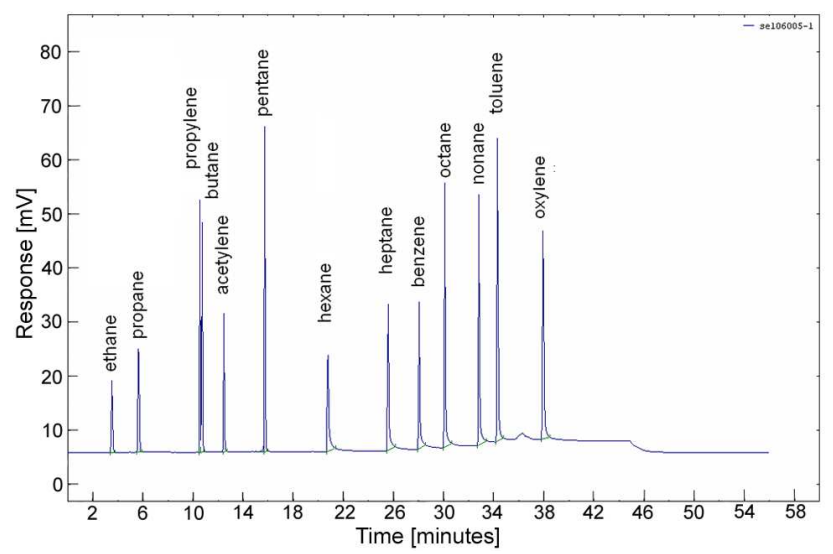

Fig. 3. Chromatograph of the standard used to determine the 13 VOCs analyzed in this work.

were prepared $24 \mathrm{~h}$ in advance and calibrated with a standard $\mathrm{UV} \mathrm{O}_{3}$ monitor (Advanced Pollution Instruments, API 400 ) and/or verified by an $\mathrm{O}_{3}$ generator (Ozonizer KTU-2). This calibration did not eliminate the interferences caused by other oxidant species, but it helped to reduce the uncertainties produced by the variations in sonde preparation.

The time required for measuring a profile up to $1000 \mathrm{~m}$ of height in intervals of $50 \mathrm{~m}$ for 10 readings of $\mathrm{O}_{3}$ and meteorology was $60 \mathrm{~min}$. For a typical profile including VOC speciation up to $200 \mathrm{~m}$ in 50-m intervals, the required time was $75 \mathrm{~min}$. The $\mathrm{O}_{3}$ and meteorological data were recorded only during ascending flights. The descents took place rapidly and no data were collected. For the analysis of both types of profiles, quasi-stationary and quasi-homogeneity conditions were assumed in an ideal boundary layer. That is, the vertical distribution of pollutants and meteorology did not change over the course of one profile measurement. These measurement durations were within the recommended time range $\left(10^{3}\right.$ to $\left.10^{4} \mathrm{~s}\right)$ for the analysis of micrometeorological observations, which depends on the height of observation, the boundary layer height, and stability (Arya, 2001). At nighttime the atmosphere is stable; therefore the atmospheric conditions as well as the vertical distribution of pollutants in the boundary layer change slowly. During daytime the boundary layer evolves faster and the time range in which atmospheric conditions can be considered stationary decreases.

Figure 2 shows the set up of the tethered balloon for measuring meteorological parameters, $\mathrm{O}_{3}$ profiles and VOC sampling. For the VOC sampling a Teflon tubing with $5 \mathrm{~mm}$ internal diameter (id) was attached to the balloon's tethered line with the inlet located at the same height of the electrochemical cell. The tubing was connected to a diaphragm pump located at the ground. Samples were introduced into $6 \mathrm{~L} \mathrm{Summa}{ }^{\circledR}$ electro-polished stainless-steel canisters for $4 \mathrm{~min}$, after flushing out the line for $10 \mathrm{~min}$ from previous sampling.
Before sampling, canisters were cleaned, evacuated and analyzed to verify the absence of VOCs. To avoid complication from storage before the analysis, sampled canisters were analyzed within $48 \mathrm{~h}$ of sampling using an automatic analyzer model GAS-3051A for atmospheric hydrocarbons (DKK Corporation, 1998). The analytical set up consisted of a dynamic dilution system, a humidity controller, a sample concentrator, and a gas chromatograph with flame ionization detection (GC-FID). The humidity controller was operated at $25^{\circ} \mathrm{C}$. Samples were preconcentrated in a multiadsorbent trap, which was packed with tenax, activated alumina and activated charcoal, and was cooled to $10^{\circ} \mathrm{C}$ by liquid carbon dioxide (industrial grade). The compounds were thermally desorbed at $250^{\circ} \mathrm{C}$ for 4 min with helium as the carrier gas (flow: $5.98 \mathrm{ml} \mathrm{min}^{-1}$ ). VOC separation was made with a Hewlett-Packard 6890 Series chromatograph, operated at constant flow of $5.98 \mathrm{~mL} \mathrm{~min}^{-1}$ and equipped with two columns connected in series; the first column was packed with alumina (length $30 \mathrm{~m}$, id $0.53 \mathrm{~mm}$ ) and the second with methylsilicone (length $30 \mathrm{~m}$, id $0.5 \mathrm{~mm}$, film thickness $1.5 \mu \mathrm{m})$. During sample loading, the oven was maintained at $40^{\circ} \mathrm{C}$ for $4 \mathrm{~min}$; subsequently the temperature was raised at a rate of $8^{\circ} \mathrm{C} \mathrm{min}{ }^{-1}$ to reach $100^{\circ} \mathrm{C}$, and then at $6^{\circ} \mathrm{C} \mathrm{min}^{-1}$ to $240^{\circ} \mathrm{C}$, the final temperature at which the oven was kept for $10 \mathrm{~min}$. The total analysis time is one hour. Individual species are identified by retention times and responses of calibration standards (1 ppmv of each monitored species, SAAN Co.) with a ten-fold dilution mixture. The detection limit is calculated to be $0.1 \mathrm{ppbv}$. Figure 3 shows a sample chromatogram obtained by this GC-FID system.

\section{Results}

This section examines the vertical distribution of $\mathrm{O}_{3}$ and VOCs in the context of the boundary layer evolution to understand their temporal and vertical variation throughout the course of the day. All profiles were examined by individual days; however, only a few measurement days covered the complete diurnal cycle, also not all the profiles reached $1000 \mathrm{~m}$ as explained above. This prevented us from obtaining a complete vertical diurnal distribution during one day of measurements. Figure 4 shows the vertical profiles of $\mathrm{O}_{3}$, potential temperature and specific humidity during one of the days with better diurnal coverage. Nevertheless, as shown in Fig. 5, all the profiles obtained were consistent even though they were measured on different days. Also, the profiles measured at the IPN and UNAM sites are similar to those measured at the CENICA site (see blue and pink profiles in Fig. 5). This consistency facilitated the interpretation of the evolution of the low urban boundary layer by plotting together the 175 profiles of $\mathrm{O}_{3}$ and meteorological parameters measured at the three different sites, and applying different normalization methods for the potential temperature and specific humidity profiles. Figure 6 shows these vertical 

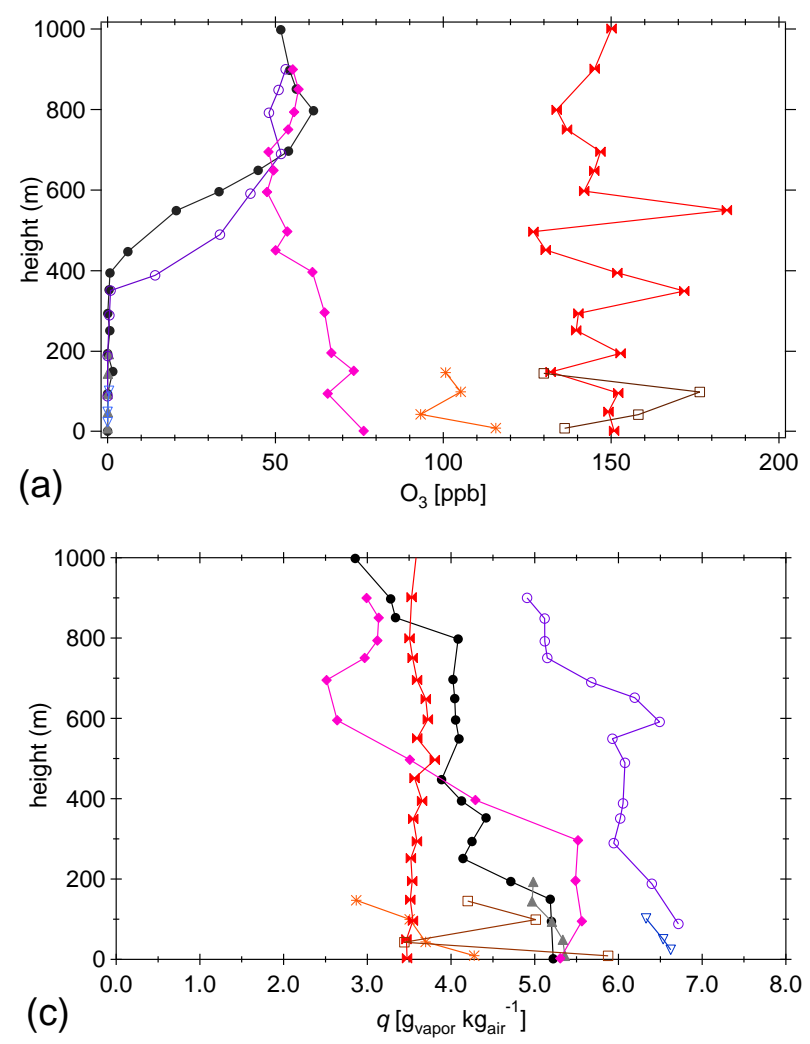

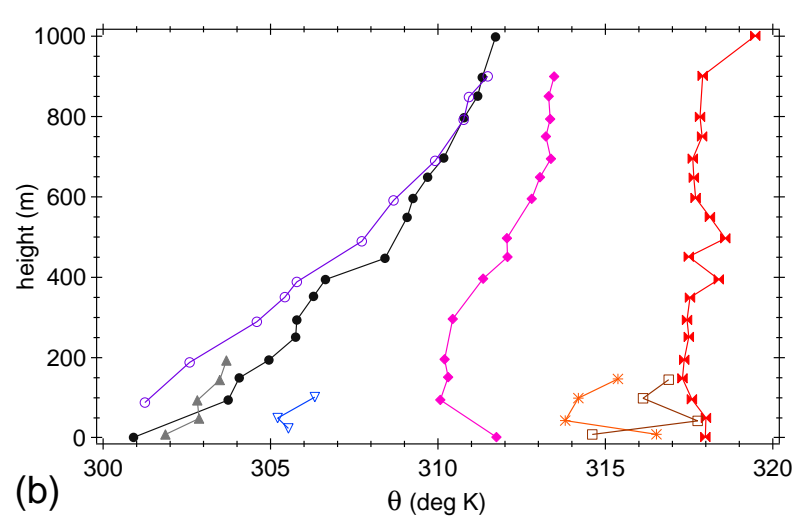

(b)

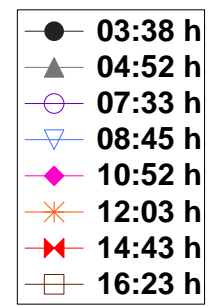

Fig. 4. Vertical profiles of $\mathrm{O}_{3}$ (a), $\theta$ (b) and $q$ (c) measured on 12/15/2000.

distributions; their characteristics are discussed in the following sections. To increase the apparent resolution of the vertical distributions, we used the interpolation function of $\mathrm{IGOR}^{\circledR}$ based on a Delaunay triangulation to generate contour lines with a setting factor of 16 . The irregular features shown in those figures are indications of the variability on the profiles due to particular meteorological conditions, random plumes or both. To identify the general features from different meteorological events, we used the meteorology classification for the Valley of Mexico proposed by de Foy et al. (2005) during the MCMA-2003 field campaign. The observed differences are discussed below.

The VOC profiles revealed also a strong consistency; however, because of a few anomalies observed, we did not utilize the same plotting routine that was used for $\mathrm{O}_{3}$ and the meteorological parameters. In some cases those anomalies could mislead the interpretation of the vertical profiles or obscure possible variations. Thus the VOC profiles were plotted without any interpolation. Figure 10 shows 13 panels with the vertical profiles for each of the VOCs analyzed. The VOCs profiles shown in seven panels (a, c, e, g, i, k, m) were classified by monitoring sites (IPN, UNAM, and CENICA), and no differences were observed between them. The other 6 panels $(b, d, f, h, j, l)$ show the profiles measured during the MCMA-2003 field campaign; they were categorized ac- cording to the prevailing meteorological event, as explained above $^{2}$.

\subsection{Vertical distribution of potential temperature and verti- cal mixing}

In an urban environment, the vertical distribution of trace gases depends strongly on the atmospheric stability and the turbulence produced by the heat released from surface and the friction produced by winds in combination with surface. To analyze the stability of the atmosphere and the ease with which air parcels can mix vertically, we computed profiles of potential temperature and a modified bulk Richardson number. The potential temperature $\theta$ is defined by Eq. (1)

$\theta=T\left(p_{0} / p\right)^{R / C_{p}}$,

where $T$ is the ambient temperature in Kelvins, $p$ is the ambient pressure, $p_{0}$ is a reference pressure usually taken as $100 \mathrm{kPa}, C_{p}$ is the specific heat of air at constant pressure and $R$ is the gas constant. For the dry conditions in Mexico City prevalent during the measurements, we used a value

\footnotetext{
${ }^{2}$ The entire set of panels showing the vertical profiles for each of the 13 VOCs classified by monitoring sites and prevailing meteorological events are available online as supplementary material with this article.
} 

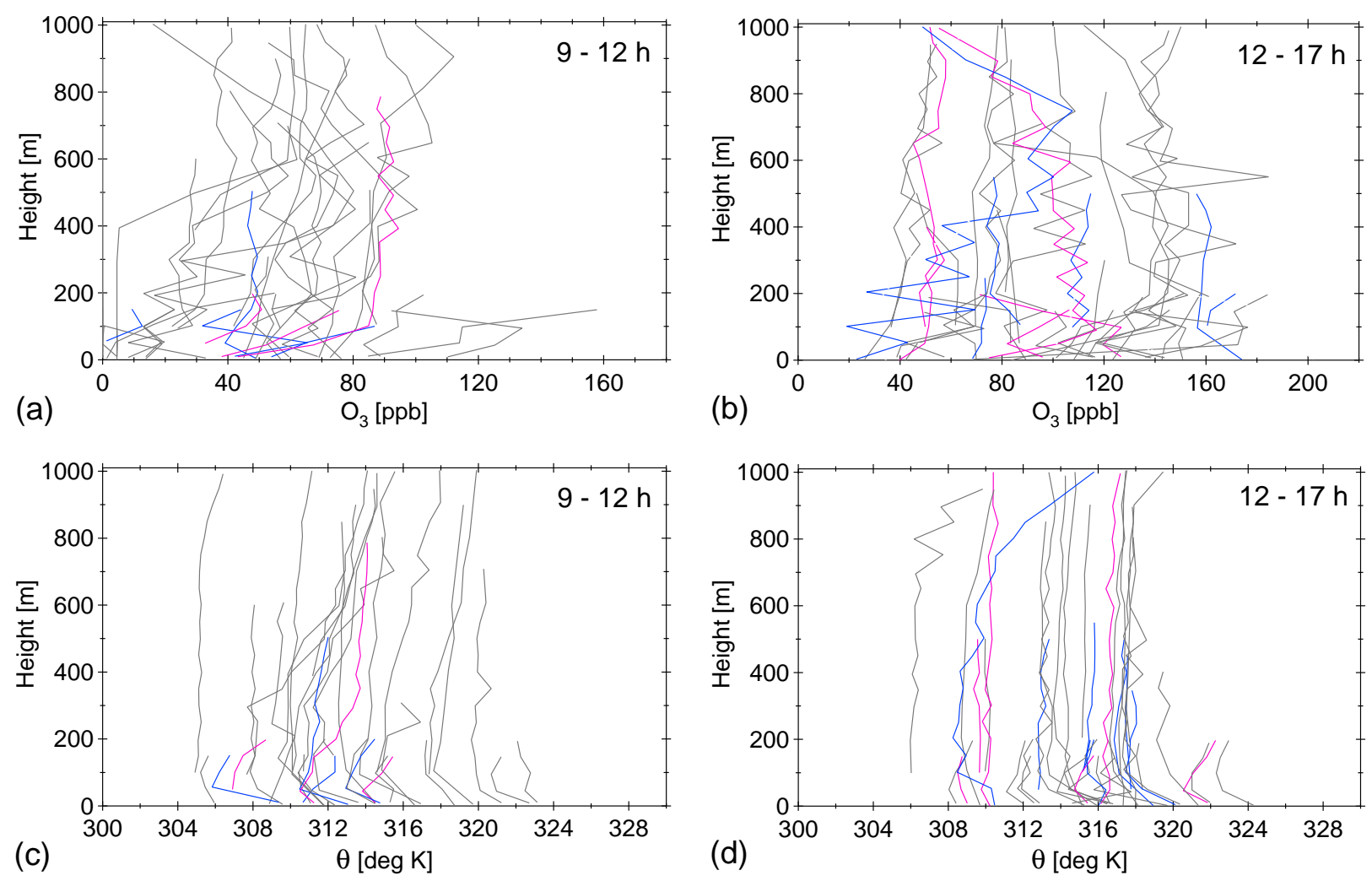

Fig. 5. Vertical profiles of $\mathrm{O}_{3}$ and $\theta$ measured during the morning (9-12h) and the afternoon (12-17 h) at the 3 different sites within the urban core of Mexico City. Profiles in gray correspond to measurements at the CENICA lab (southeast), in blue at the UNAM (southwest), and in pink at the IPN (north).

of 0.286 for the $R / C_{p}$ ratio. The modified bulk Richardson number was calculated from Eq. (2):

$R_{B}=\frac{g \Delta \overline{\theta_{v}} \Delta z}{\overline{\theta_{v}}(\Delta U)^{2}}$,

where $g$ is the acceleration of gravity, $\overline{\theta_{v}}$ is the average virtual potential temperature over a specific depth $\Delta z, \Delta \overline{\theta_{v}}$ and $\Delta U$ are the differences in the virtual potential temperature and wind speed over $\Delta z$, respectively. $\Delta z$ is the difference in meters between a specific height of the vertical profile and the lowest height at which the sonde tethered to the balloon collected data (between 10 and $50 \mathrm{~m}$ ). We assumed that at the bottom height $U \approx 0$; therefore $\Delta U=U$. The term $\theta_{v}$ includes the buoyant effects of water vapor in the potential temperature; it is defined by Eq. (3):

$\theta_{v}=\theta(1+0.61 r)$,

where $r$ is the mixing ratio of water vapor; it is calculated from the partial pressure water term, which is obtained from the measured temperature, pressure and relative humidity (Stull, 1988).

To better observe the atmospheric stability through the $\theta$ vertical distribution, we have plotted in Fig. 6a the differences in $\theta$ at each height for each profile using $\theta$ at $100 \mathrm{~m}$ as reference $\left(\Delta \theta_{@ 100 \mathrm{~m}}=\theta_{i}-\theta_{100 \mathrm{~m}}\right)$, instead of plotting the absolute $\theta$ values. A positive $\Delta \theta @ 100 \mathrm{~m}$ value indicates a stable stratified atmosphere, while a negative value indicates a neutral or unstable atmosphere. Figure $2 b$ shows the vertical distribution of the modified bulk Richardson number described above. Large positive values of $R_{B}$ indicate greater dynamic stability, while negative values or close to zero indicate a greater probability of vertical mixing. There is no well-defined critical value of $R_{B}$ above which turbulence ceases (Stull, 1988), but it has been accepted that for $R_{B}$ greater than one, vertical mixing is suppressed. Note that the bulk Richardson number is a ratio that by itself does not provide information about the intensity of turbulence; it only indicates the presence or absence of turbulence. Although it relies on several variables and assumptions, and therefore subjects to uncertainties that are difficult to quantify, it has demonstrated to be a valuable tool for investigating the atmospheric stability using tethered balloons or other platforms, such as tall towers (i.e., Doran et al., 2003; Lee et al., 2003; Galbally, 1968).

At nighttime the $\theta$ profile is characterized by nocturnal inversion, which is produced by radiative cooling of the surface. The nocturnal boundary layer is usually stable in the 

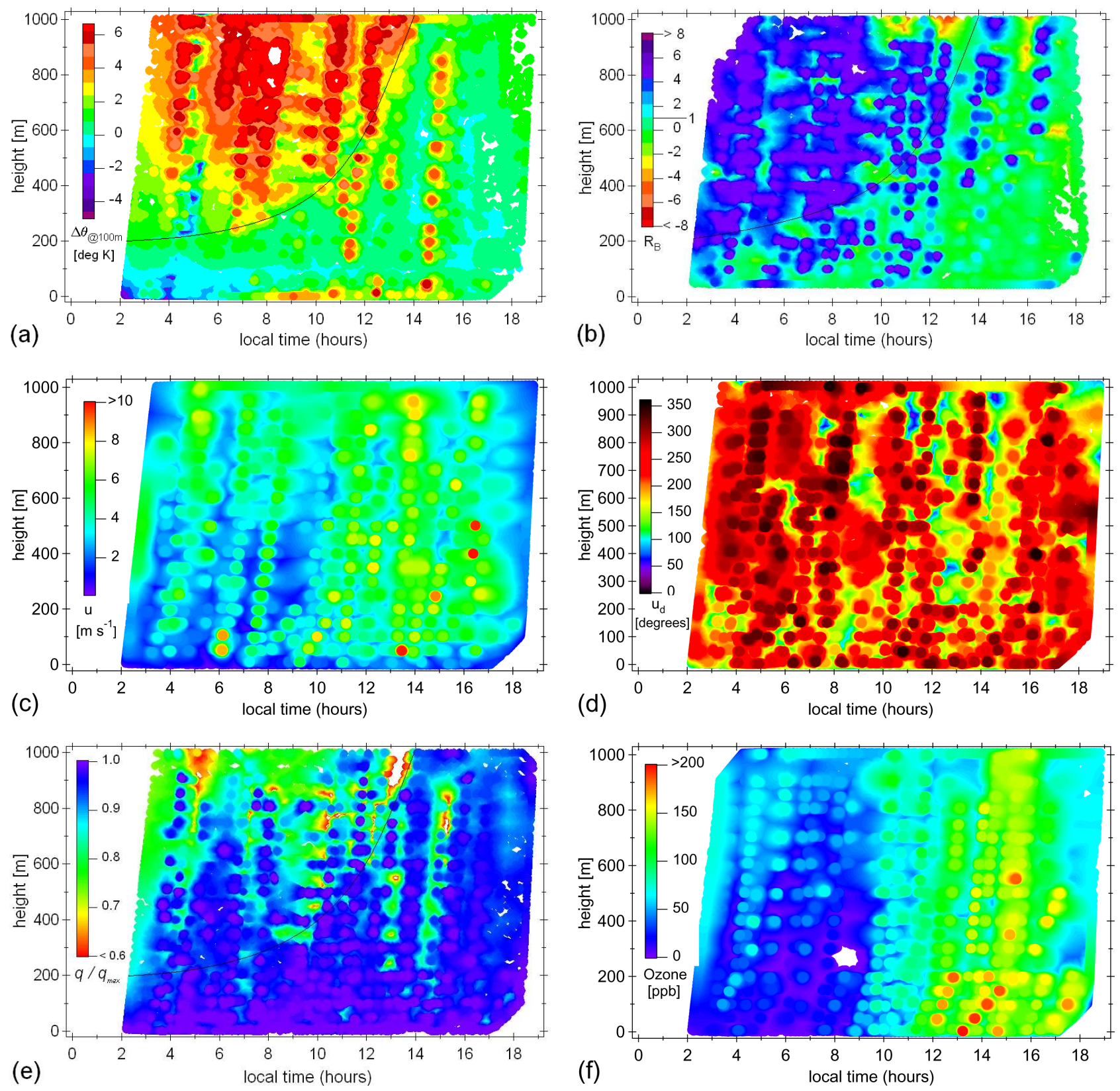

Fig. 6. Vertical distributions of different meteorological parameters and $\mathrm{O}_{3}$ throughout the course of the day: (a) differences in $\theta$ at each height using $\theta$ at $100 \mathrm{~m}$ as reference $\left(\Delta \theta_{@ 100 \mathrm{~m}}=\theta_{i}-\theta_{100 \mathrm{~m}}\right) . \Delta \theta_{@ 100 \mathrm{~m}}>0$ indicates a stable stratified atmosphere; $\Delta \theta_{@ 100 \mathrm{~m}}<0$ indicates a neutral or unstable atmosphere; (b) modified bulk Richardson number: $R_{B}<1$ indicates a high probability of vertical mixing; $R_{B}>1$ indicates dynamic stability; (c) wind speed; (d) wind direction; (e) normalized specific humidity $\left(q / q_{\max }\right)$; (f) $\mathrm{O}_{3}$ concentration. The black line in Fig. 2a, b, e indicates the evolution of the CBL.

absence of turbulence $\left(R_{B}>1\right.$ and $\left.\Delta \theta_{@ 100 \mathrm{~m}}>1\right)$ above $200 \mathrm{~m}$ until sunrise $(\sim 7: 00 \mathrm{~h})$. Below that altitude the turbulence is almost always present $\left(R_{B}<1\right)$. At night the turbulence is maintained by the wind and roughness of the city, but mainly by the release of the heat stored in the buildings and urban surface during daytime. Figure 7 shows the energy balance for a typical day of the dry-warm season in Mexico City measured during the 2006 MILAGRO field campaign. Although this energy balance was measured at a different site close to the center of the city, it gives insight on the nocturnal release of energy. During daytime the term of the storage heat $\left(\Delta Q_{s}\right)$ in the energy balance represents $50 \%$ of the net radiation $(Q *)$ in the urban core of Mexico City. At nighttime the $\Delta Q_{s} / Q *$ ratio is positive and greater than one, which explains the turbulence presence in the surface layer. 


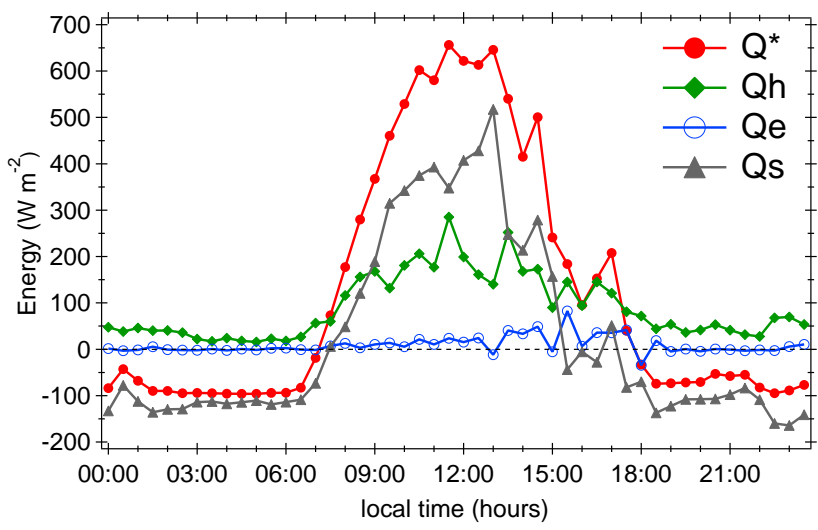

Fig. 7. Energy balance measured on 24 March 2006 in the urban core of Mexico City during the MILAGRO field campaign. The sensible $\left(Q_{h}\right)$ and latent $\left(Q_{e}\right)$ heats were measured by eddy covariance, $Q *$ by a net radiometer and $\Delta Q_{s}$ was obtained as the residual of the measured energy components $\left(\Delta Q_{s}=Q *-\left(Q_{h}+Q_{e}\right)\right)$.

Shortly after sunrise, surface heating leads to an upward exchange of sensible heat and subsequent warming of the lowest layer due to heat flux convergence. After 07:00 h the surface boundary layer becomes warmer than the air above. Figure 6a shows this morning heating through positive $\Delta \theta_{@ 100 \mathrm{~m}}$ values below $100 \mathrm{~m}$. By $09: 00 \mathrm{~h}$ the air at the surface layer is between 2 and $3^{\circ} \mathrm{C}$ warmer than the air at $100 \mathrm{~m}$. This process progressively erodes the nocturnal inversion from below and replaces it with an unstable or convective boundary layer (CBL). The CBL is characterized by vigorous vertical mixing with constant or small negative $\Delta \theta_{@ 100 \mathrm{~m}}$ values and $R_{B}$ values below one. The depth of the CBL grows with time; Fig. 6a shows that negative $\Delta \theta_{@ 100 \mathrm{~m}}$ values reach higher altitudes during the morning at a similar rate as $R_{B}$ values below one appear at those altitudes in Fig. $6 \mathrm{~b}$. The boundary layer passes from $\sim 200 \mathrm{~m}$ at $07: 00 \mathrm{~h}$ to $\sim 600 \mathrm{~m}$ by midday. The rate of growth of the CBL in Mexico City is not as fast as typically in some other places, where the maximum rate of growth is attained within a few hours after sunrise (Arya, 2001). The vertical distributions of $\Delta \theta_{@ 100 \mathrm{~m}}$ and $R_{B}$ show that the maximum rate of growth occurred between one and two hours after midday, when the boundary layer depth reached $1000 \mathrm{~m}$. Our findings are consistent with those obtained from the IMADA-AVER boundary layer experiment (Doran et al., 1998; Whiteman et al., 2000) conducted during the dry season in Mexico City, in which the boundary layer grows slowly after sunrise to a depth under $1000 \mathrm{~m}$ before noon, then grows rapidly to heights of $3000 \mathrm{~m}$ or more within the subsequent few hours.

According to Whiteman et al. (2000), after the rapid growth stage of the boundary layer in Mexico City ending between 13:00 and 14:00 $\mathrm{h}$, a quenching stage follows in which the rate of heating and growth are slowed during the next two hours. Then a rapid and deep cooling stage occurs with a col- lapse of the boundary layer. Because of the height limitations in our measurements, we could not observe these two stages of the boundary layer, nor determine its maximum growth. We observed only an unstable atmosphere and a vigorous vertical mixing in the $1000-\mathrm{m}$ layer above the ground between 14:00 $\mathrm{h}$ and few minutes before 18:00 h. After 18:00 h positive values of $\Delta \theta_{@ 100 \mathrm{~m}}$ started to appear above $\sim 600 \mathrm{~m}$, indicating the collapse of the CBL and the formation of a new residual layer. Although only a few measurements were made after 18:00 h, they were sufficient to show this event, which is related to the formation of $\mathrm{O}_{3}$ pool at that height and will be discussed later.

The evolution of the boundary layer in terms of the energy balance has been described by Whiteman et al. (2000). They suggested that the falloff of the rate of heat storage from the energy balance between 13:00 and 14:00 h (see Fig. 7) could be interpreted as quenching of the boundary layer growth caused by the leakage of cold air into the warm basin atmosphere from the colder surroundings of the valley where Mexico City is located. The formation of the residual layer around 18:00 $\mathrm{h}$ occurs when the heat storage term changes sign, and when the release of the stored heat in the urban surface begins.

\subsection{Vertical profiles of wind speed and direction}

Figure $6 \mathrm{c}$ shows the vertical profiles of the horizontal wind speed throughout the course of the day, and Fig. 6d shows the vertical distribution of the wind direction. While our measurements were unable to describe the diurnal and spatial variations of the boundary layer winds in Mexico City, they provided a glimpse of the winds in the lower boundary layer over the southeast part of the city as long as the wind speeds were low enough to safely launch the tethered balloon. Overall, weak winds blowing from the northwest and the west prevail in the residual layer until a few hours after sunrise. The surface winds attain minimum values before sunrise, and increase during the day reaching maximum values in the afternoon. As the CBL evolves during the morning and early afternoon, the wind speed becomes uniform in the 1000 -m layer above the ground, excluding the surface layer, which is characterized by a strong gradient. After midday, the wind direction becomes more variable in the vertical profile during the next three hours, coinciding with the rapid growth stage of the boundary layer. This is due to the vigorous vertical mixing produced by the heating of the CBL. After this stage, the winds tend to blow again from the north and the west. Detailed descriptions of the wind diurnal variations in Mexico City are provided by Whiteman et al. (2000) and de Foy et al. (2005), particularly for the dry season when the bulk of our measurements were made. During this season, Mexico City is normally under the influence of anticyclone weather with light westerly winds above the valley and nearly cloudless skies. 

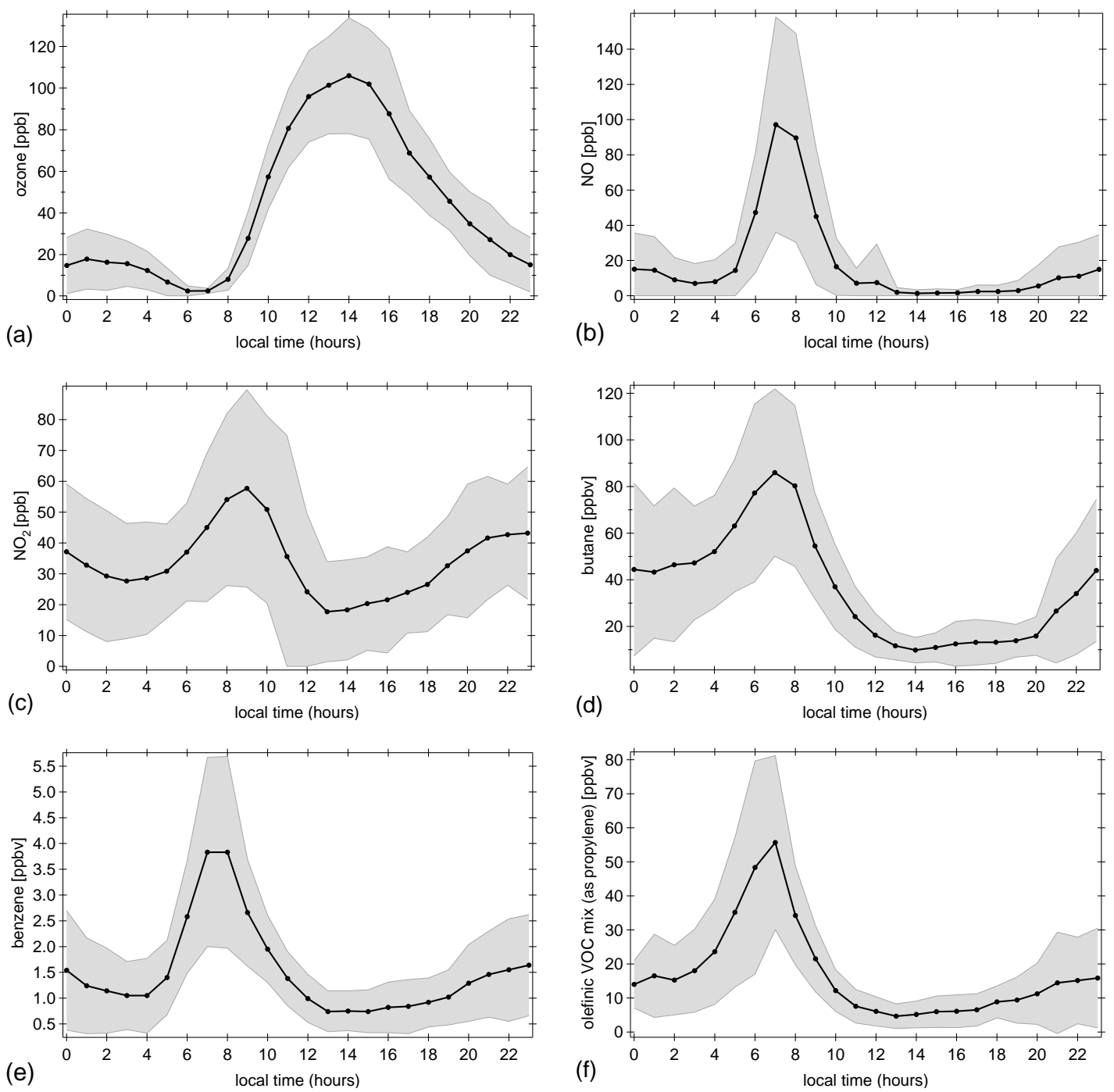

Fig. 8. Average diurnal patterns of different trace gases measured at ground level at the CENICA supersite during April 2003 (see Molina et al., 2007 and the references therein). (a) $\mathrm{O}_{3}$ measured by UV Differential Optical Absorption Spectrometry (DOAS); (b) NO measured by a standard chemiluminescence monitor; (c) $\mathrm{NO}_{2}$ measured by a standard chemiluminescence monitor; (d) butane measured by Fourier Transform Infra Red Spectroscopy (FTIR); (e) benzene measured by DOAS; (f) mix of olefinic VOCs responding as propylene measured by a Fast Isoprene Sensor (Guenther and Hills, 1998). The gray shadows represent one standard deviation ranges, and give an indication of the day-to-day variability in each phase of the daily cycle.

\subsection{Vertical distribution of humidity}

To illustrate the vertical changes in the specific humidity $(q)$, we have normalized each profile to its maximum measured value in Fig. 6e. We observed that evapotranspiration of the urban surface is enough to produce abrupt gradients throughout most of the day, from early morning to early afternoon. During early morning and a few hours after sunrise, the turbulence and unstable conditions of the surface layer produce a layer of $350 \mathrm{~m}$ deep above the ground with uniform values of $q$. Within one to two hours after sunrise, $q$ attains maximum values up to $12 \mathrm{~g} \mathrm{~kg}^{-1}$ in this layer. Sometimes this is enhanced by the water vapor condensation and deposition on the surface in the form of dew before sunrise when winds are weak and the surface temperature falls below the dew point of the moist air near the surface. Before sunrise, the residual layer above $500 \mathrm{~m}$ shows nearly uniform profiles for $q$, about 30 to $45 \%$ lower than in the lowest layer. After sunrise, as the boundary layer evolves, the moisture in the lowest layer mixes with the air in the upper layers, producing nearly uniform profiles within the CBL. Throughout the morning and early afternoon $q$ decreases, attaining minimum values of 1 to $4 \mathrm{~g} \mathrm{~kg}^{-1}$ between 13:00 and 15:00 $\mathrm{h}$, when the solar radiation is the strongest. During the afternoon $q$ rises 
slowly again, reaching values close to $6 \mathrm{~g} \mathrm{~kg}^{-1}$ by $18: 00 \mathrm{~h}$. This period coincides with the rapid and deep cooling stage that drives the decay of the boundary layer.

\subsection{Vertical distribution of ozone}

Figure 8 shows the average diurnal patterns of $\mathrm{O}_{3}$ and other trace gases measured at ground level at the CENICA site as part of the MCMA-2003 field campaign (Molina et al., 2007), which was carried out during the dry season in April 2003. As expected, the $\mathrm{O}_{3}$ concentration shows a distinct diurnal pattern, a minimum in the morning and a maximum in the early afternoon. This diurnal pattern extends to the shallow unstable boundary layer at night and the CBL during daytime (Fig. 6f). Figure 9 shows the $\mathrm{O}_{3}$ vertical profiles normalized to their maximum concentrations during different periods of the day and classified by the climatic season when they were obtained (only those profiles that reached at least $500 \mathrm{~m}$ are included).

At nighttime, the presence of the nocturnal inversion layer isolates the ground-level $\mathrm{O}_{3}$ from that of the upper levels. Surface $\mathrm{O}_{3}$ is removed by deposition and titration with nitric oxide (NO) emitted from evening traffic. Since no $\mathrm{O}_{3}$ is produced in the absence of sunlight at night, $\mathrm{O}_{3}$ concentration decreases after sunset, attaining minimum values by sunrise, between $06: 00$ and $08: 00 \mathrm{~h}$, when $\mathrm{NO}$ is rapidly converting hydroperoxy radical $\left(\mathrm{HO}_{2}\right)$ to hydroxyl radical $(\mathrm{OH})$ and $\mathrm{NO}_{2}$ is rapidly converting $\mathrm{OH}$ to nitric acid $\left(\mathrm{HNO}_{3}\right)$. The $\mathrm{O}_{3}$ confined in the nocturnal stable boundary layer aloft creates a residual layer of $\mathrm{O}_{3}$ shielded from $\mathrm{NO}$ and VOCs emissions. The beginning of this residual layer occurs at $\sim 18: 00 \mathrm{~h}$ of the previous day, when the release of the stored heat in the urban surface begins and the CBL starts to collapse. A clear and well-established residual layer is observed above $500 \mathrm{~m}$. Accumulation of $\mathrm{O}_{3}$ starts at $200 \mathrm{~m}$, coinciding with the cut off of the nocturnal unstable layer, but in some cases it can start at $100 \mathrm{~m}$. An interesting seasonal feature is the $\mathrm{O}_{3}$ gradient from 200 to $500 \mathrm{~m}$, which shows a relatively constant rate of $\sim 0.1 \mathrm{ppbv} \mathrm{m}^{-1}$ during the dry-warm season. In contrast, no gradient is observed during the dry-cold season; the residual layer appears abruptly above $300 \mathrm{~m}$, as shown in Fig. 9a. However, more measurements are needed to confirm and explain this feature. The $\mathrm{O}_{3}$ concentration in the residual layer depends on the $\mathrm{O}_{3}$ level from the previous day and meteorological conditions; on average the observed $\mathrm{O}_{3}$ concentration in the residual layer was $35 \mathrm{ppbv}$, which is consistent with the background level observed in the surrounding regions of the Valley of Mexico. Concentrations above 50 ppbv were typical and the maximum concentration observed within this layer was $75 \mathrm{ppbv}$. Usually, the venting of the urban plume is very efficient and this $\mathrm{O}_{3}$ aloft is transported to the surrounding regions (de Foy et al., 2006).

After sunrise, the height of the unstable boundary layer begins to increase as the surface is heated and the nocturnal inversion is destroyed, resulting in downward mixing $\mathrm{O}_{3}$ from aloft. Surface $\mathrm{O}_{3}$ is also locally generated by reactions of $\mathrm{NO}_{\mathrm{x}}$ with VOCs in the presence of sunlight. Consequently, one would expect a rapid increase in the $\mathrm{O}_{3}$ concentration. However, during the next two hours after sunrise, $\mathrm{O}_{3}$ remains constant, even though it is being rapidly produced. $\mathrm{O}_{3}$ production rates exceed $50 \mathrm{ppbv} \mathrm{h}^{-1}$ as early as one hour after sunrise (Shirley et al., 2006), but this production is not detectable because fresh $\mathrm{O}_{3}$ and mixed $\mathrm{O}_{3}$ downward from the residual layer are depleted by reaction with $\mathrm{NO}$, forming $\mathrm{NO}_{2}$ (see Fig. $8 \mathrm{~b}$ and c) and then $\mathrm{HNO}_{3}$, thus increasing the nitrate content of the particles. Salcedo et al. (2006) suggested that one third of the $\mathrm{HNO}_{3}$ goes to the particle phase. The available NO from nighttime emissions trapped in the shallow unstable boundary layer plus the fresh emitted NO during the morning rush-hour period $(05: 30$ to $09: 30 \mathrm{~h})$ is enough to delay the rise of the ambient $\mathrm{O}_{3}$ concentration by about $2 \mathrm{~h}$.

After the morning $\mathrm{O}_{3}$ balance determined by photochemical production, entrainment from the residual layer, and destruction by titration with $\mathrm{NO}$, the ground-level $\mathrm{O}_{3}$ concentration jump up around 09:00 h, when NO had fallen to half its peak value (see Fig. 8b). As the CBL evolves during the subsequent hours, the $\mathrm{O}_{3}$ entrainment from upper layers continues, and contributes to new $\mathrm{O}_{3}$ formed by the combination of high $\mathrm{OH}$ reactivity, strong solar radiation and abundant $\mathrm{NO}_{\mathrm{x}}$, and quite possibly, also from high levels of morning acetaldehyde $\left(\mathrm{CH}_{3} \mathrm{CHO}\right)$ and formaldehyde $(\mathrm{HCHO})$ emissions (Zavala et al., 2006; Garcia et al., 2006). During the MCMA-2003 field campaign, Shirley et al. (2006) measured $\mathrm{OH}$ reactivity peak values of $\sim 120 \mathrm{~s}^{-1}$ in the morning rushhour period and observed that the $\mathrm{OH}$ reactivity followed a similar diurnal pattern for $\mathrm{NO}_{\mathrm{x}}$ and VOCs, suggesting that traffic emissions are the main cause of the high $\mathrm{OH}$ reactivity that drives the photochemical smog formation in Mexico City. They calculated that VOCs contribute $72 \%$ to the $\mathrm{OH}$ reactivity, $\mathrm{NO}_{\mathrm{x}} 12 \%, \mathrm{CO} 7 \%$ and $\mathrm{HCHO} 4 \%$. Volkamer et al. (2007) did a detailed analysis of $\mathrm{OH}, \mathrm{HO}_{2}$ and $\mathrm{RO}_{2}$ radical sources and identified alkenes as responsible for jump-starting the morning photochemistry. Between 09:00 and 11:00 h, the accumulated $\mathrm{O}_{3}$ in the upper layers is still there, but at higher altitudes (Fig. 9c). At ground level the $\mathrm{O}_{3}$ production attains maximum values up to $\sim 100 \mathrm{ppbv}^{-1}$ (Shirley et al., 2006) as a result of the high radical production rate and active photochemistry enhanced by the trapping of pollutants within the CBL, particularly secondary species, such as HCHO and oxygenated VOCs (Volkamer et al., 2007). The reaction of NO with peroxy radicals from VOC oxidation and $\mathrm{O}_{3}$ produces peak $\mathrm{NO}_{2}$ concentrations during mid-morning (Fig. 8c). Between 10:00 and 12:00 h, as a result of the accumulation of fresh $\mathrm{O}_{3}$ beneath the residual layer plus the mixed $\mathrm{O}_{3}$ downward, the $\mathrm{O}_{3}$ concentration within the CBL reaches at least $50 \%$ of the concentration in the remaining residual layer (Fig. 9d), while the $\mathrm{NO}_{2}$ level decreases due to the CBL evolution and chemical loss (i.e., photolysis and $\mathrm{HNO}_{3}$ formation). After midday, during 

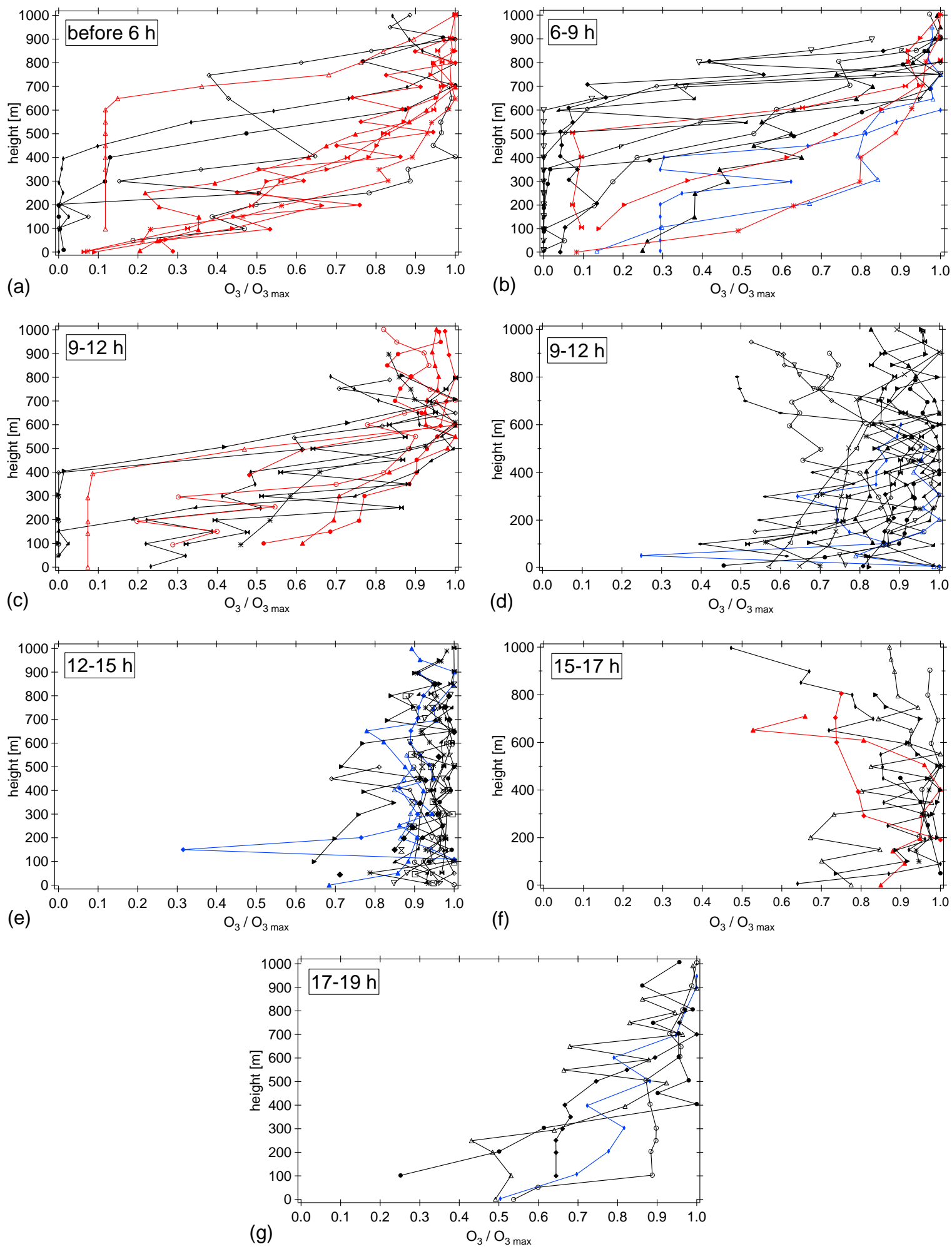

Fig. 9. $\mathrm{O}_{3}$ vertical profiles normalized to their maximum concentrations during different diurnal periods and classified by the climatic season when they were measured: dry-cold season (black); dry-warm season (red); and rainy season (blue). 
the next three hours the vertical $\mathrm{O}_{3}$ distribution is uniform (Fig. 9e) as a consequence of the efficient vertical mixing during the rapid growth stage of the boundary layer. During this period, $\mathrm{O}_{3}$ attains maximum concentrations between 120 and $150 \mathrm{ppbv}$ and occasionally reaches $180 \mathrm{ppbv}$, as well as the $\mathrm{OH}$ and $\mathrm{HO}_{2}$ radicals, while $\mathrm{NO}_{\mathrm{x}}$ attains minimum concentrations (Shirley et al., 2006). The $\mathrm{O}_{3}$ production decreases continuously during the afternoon, as a result of decreasing $\mathrm{OH}$ reactivity, and the loss of $\mathrm{NO}_{\mathrm{x}}$ to $\mathrm{PAN}$ and other organic nitrates. Using a chemical transport model, Lei et al. (2007) determined that the $\mathrm{O}_{3}$ production during the afternoon depends not only on $\mathrm{NO}_{\mathrm{x}}$, but also on VOC reactivity and radicals sources, suggesting that the $\mathrm{O}_{3}$ formation in Mexico City is VOC-limited after midday (reducing VOCs would lead to a drop in $\mathrm{O}_{3}$ production, in contrast to a similar reduction in $\left.\mathrm{NO}_{\mathrm{x}}\right)$. After 15:00 h, the intensity of sunlight diminishes (see Fig. 7), and enhances the reduction on the $\mathrm{O}_{3}$ production. Furthermore, the wind intensity increases in the afternoon enhancing the pollutants dispersion and the valley's ventilation, which helps to reduce the $\mathrm{O}_{3}$ concentration and destroys the uniform profiles of $\mathrm{O}_{3}$ within the CBL (Fig. 9f). In late afternoon, the cooling of the atmosphere and the collapse of the CBL drive the formation of a new $\mathrm{O}_{3}$ residual layer, beginning a few minutes before sunset (Fig. 9g).

The irregular features observed in the $\mathrm{O}_{3}$ profiles are caused by variations of the solar radiation intensity due to absorption and scattering by clouds, local emissions of $\mathrm{O}_{3}$ precursors, efficiency of $\mathrm{O}_{3}$ production, and dispersion processes.

\subsection{Vertical distribution of VOCs}

Figure 10 shows the vertical distribution for each of the 13 VOCs monitored. Overall, no differences were observed in the VOCs concentrations within the 200-m layer above the ground due to the efficient vertical mixing, except during the morning rush-hour period when the profiles showed the highest concentrations and largest variability between different days. The VOCs concentrations within this layer follow the diurnal pattern of the concentrations measured at ground level. For example, Fig. 8 shows the diurnal concentrations of butane, benzene and the olefinic VOC mixture (as propylene) measured continuously at the surface during the MCMA-2003 field campaign. The parcels with higher concentrations within this layer may be due to transport of local plumes, and less likely from artifacts in our measurements, such as folds, leaks or ruptures in the sampling line due to sudden changes from wind and/or turbulence intensity. Some of these parcels were near the surface and their high VOC concentration was due to fresh emissions from local sources. A gradient in the concentrations close to the surface $(\sim 40 \mathrm{~m})$ can be expected due to the time needed for the turbulence produced in the roughness sublayer to blend the fresh emissions. The chemical reactions with $\mathrm{OH}$ radical are too slow to produce significant gradients in the vertical distribution. The turbulence mixes the VOCs in the unstable boundary layer much faster than the $\mathrm{OH}$ radical depletes them. For example, propylene, the most reactive of the 13 measured VOCs, has a lifetime of $1 \mathrm{~h}$ at midday when $\mathrm{OH}$ attains maximum concentrations of 0.4 pptv (Shirley et al., 2006), compares to the average time of 4 min that an air parcel takes to travel from the surface to $200 \mathrm{~m}$, as reported from turbulent flux measurements in Mexico City by Velasco et al. (2005).

The diurnal patterns of VOCs depend on the anthropogenic activities, photochemistry and meteorology. All VOCs reach their highest level during the morning rushhours and show strong variability within the 200-m layer, in contrast to the rest of the day. This period coincides with the beginning of the formation of a new CBL when the unstable boundary layer is shallow, the traffic emissions are intense and the $\mathrm{OH}$ and $\mathrm{HO}_{2}$ levels are low. The tethered balloon measurements do not indicate a specific height at which the VOCs accumulate, instead they show that the variability in the VOCs concentrations within this layer is similar to the variability observed from ground-level measurements (see Fig. 8d-f). For example, the bulk of the benzene concentrations observed in the vertical profiles within this period varied between 1.5 and $6 \mathrm{ppbv}$, similar to the observed concentration range at ground level. After this period the VOCs level decreases due to photochemical reactions and the dilution produced by the CBL evolution. The rapid formation of glyoxal (CHOCHO) shortly after sunrise observed by Volkamer et al. (2005) during the MCMA-2003 field campaign revealed a very efficient $\mathrm{VOC}$ oxidation process during morning hours. $\mathrm{CHOCHO}$ is formed from the oxidation of numerous VOCs; it is a good indicator for VOC oxidation processes because it does not react with $\mathrm{NO}$ and it is essentially unaffected by traffic emissions. The CHOCHO level remains high until early afternoon, indicating a persistently active VOC chemistry throughout most of the day. The VOC oxidation is initiated by radicals (i.e., $\mathrm{OH}, \mathrm{HO}_{2}$ and $\mathrm{RO}_{2}$ ), $\mathrm{O}_{3}$ and photolysis. Volkamer et al. (2007) identified nitrous acid ( $\mathrm{HONO}$ ), $\mathrm{O}_{3}, \mathrm{HCHO}$, the reactions between $\mathrm{O}_{3}$ and alkenes, and photolysis of secondary oxygenated VOCs as the dominant radical sources during daytime; whereas the reaction of alkenes with $\mathrm{O}_{3}$, and to a minor extent reaction of alkenes and nitrates, are the main radical sources at nighttime. Further, the dark reaction of alkenes with $\mathrm{O}_{3}$ leads to the accumulation of secondary pollutants that produce radicals in the early morning hours.

The low molecular weight alkanes (ethane, butane and propane) show similar vertical and diurnal distributions. The high ambient concentrations of propane and butane are attributed mainly to liquefied petroleum gas (LPG) combustion and leakage during handling, distribution and storage. LPG is the main fuel used for cooking and water heating in Mexican households. Although LPG powered vehicles represent less than $1 \%$ of the total fleet, they are also important 

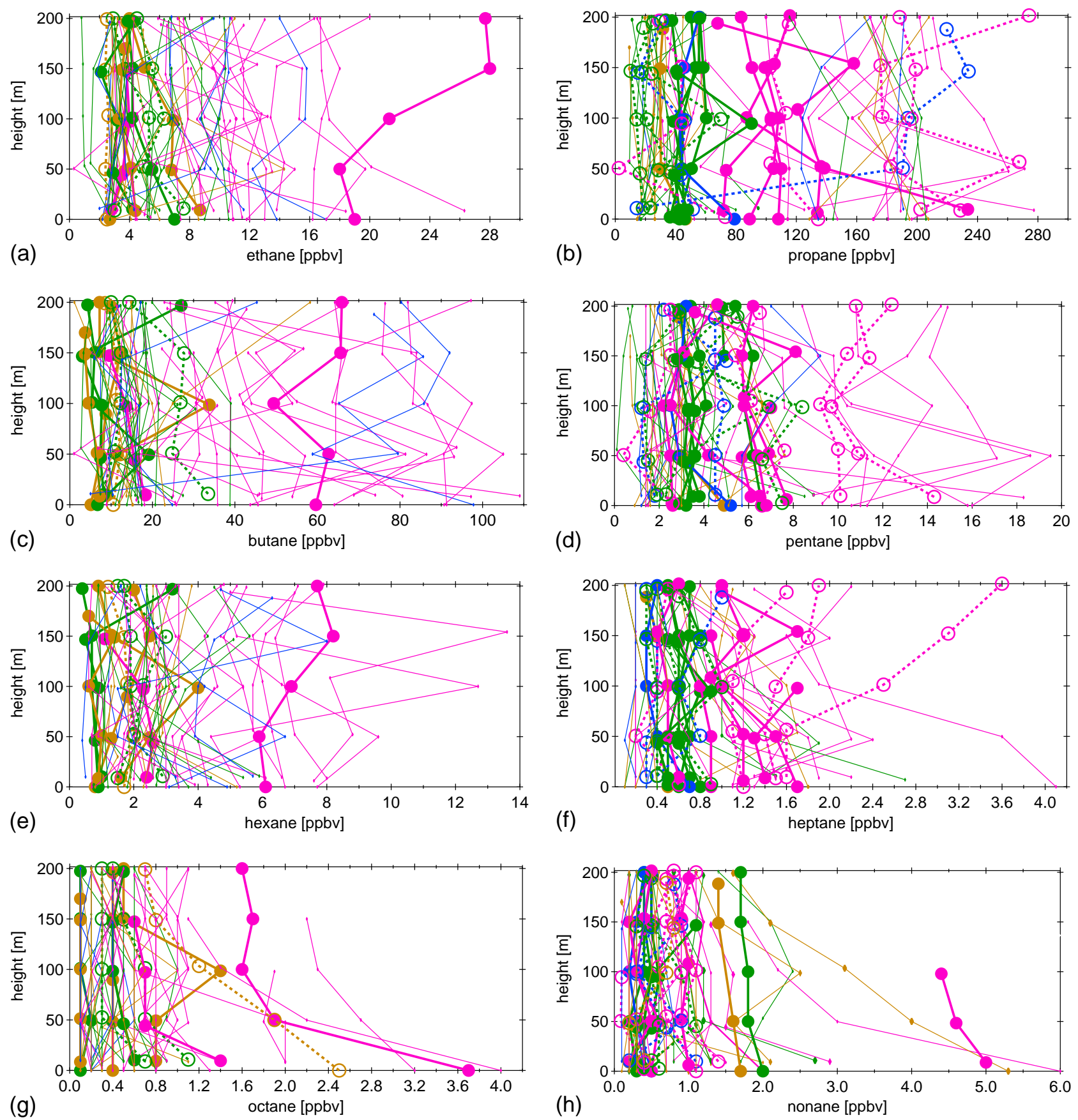

Fig. 10. Vertical distributions of the 13 VOCs monitored. (a) Ethane, (b) propane, (c) butane, (d) pentane, (e) hexane, (f) heptane, (g) octane, (h) nonane, (i) propylene, (j) acetylene, (k) benzene, (l) toluene, $(\mathbf{m})$ o-xylene at different periods of the day. Blue: before sunrise (02:00 to $05: 30 \mathrm{~h}$ ); pink: morning rush-hour period $(05: 30$ to $09: 30 \mathrm{~h})$; green: late morning and early afternoon $(09: 30$ to $14: 00 \mathrm{~h})$; and brown: afternoon (after 14h). Profiles in the left panels (a, c, e, g, i, k, m) are classified by monitoring site: open circles (UNAM), filled circles (IPN), and the rest at the CENICA lab. Profiles in the right panels (b, $\mathrm{d}, \mathrm{f}, \mathrm{h}, \mathrm{j}, \mathrm{l}$ ) represent those profiles measured on $\mathrm{O}_{3}$-North (open circles) and Cold Surge (filled circles) days during the MCMA-2003 field campaign. 

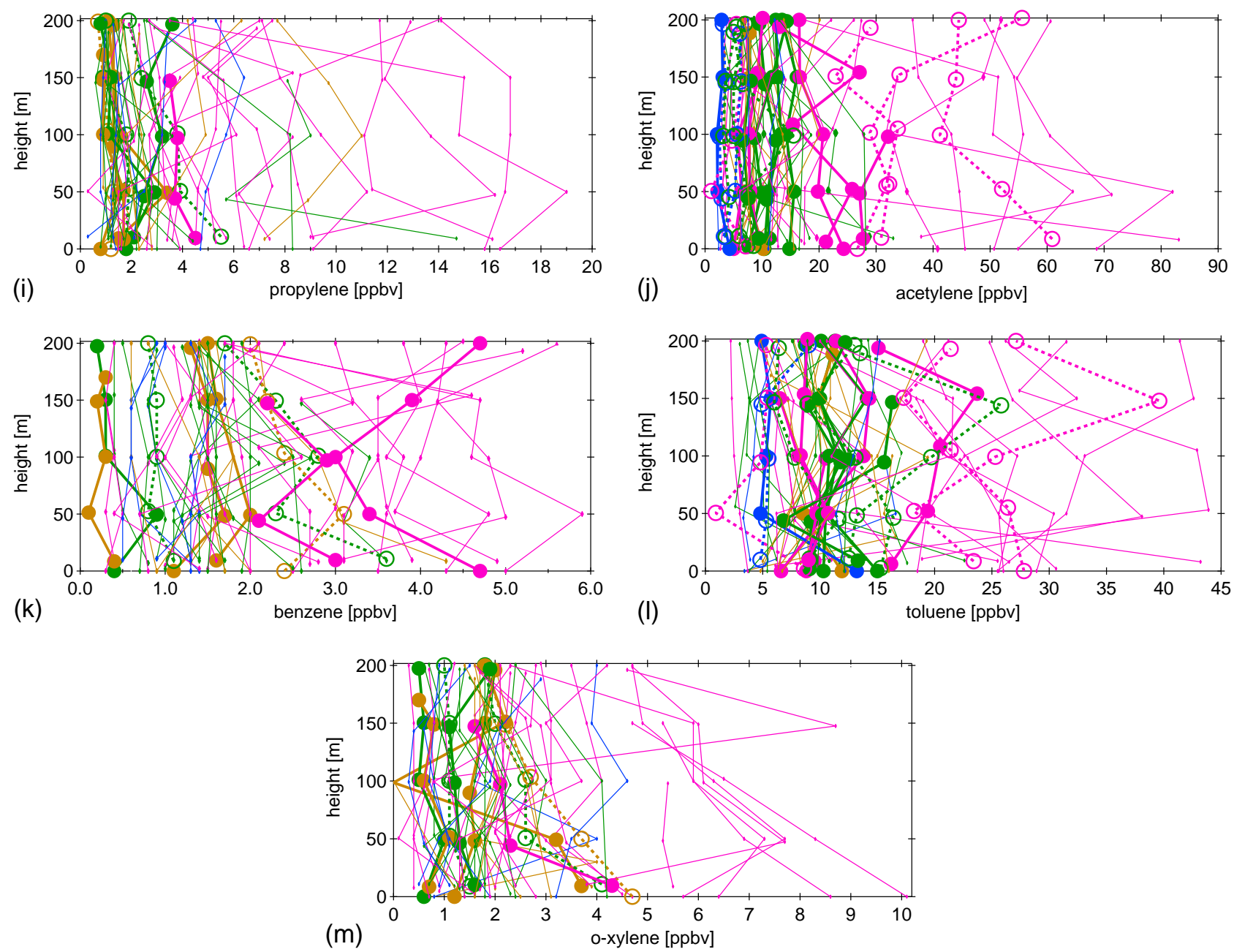

Fig. 10. Continued.

emission sources. The LPG fleet is composed mainly of vehicles used intensively (light and heavy duty trucks, and microbuses with 20-passenger capacity); $95 \%$ of them have emissions that exceed the standards required by local environmental regulations (Schifter et al., 2000). The LPG leaked from households at nighttime accumulates in the shallow unstable boundary layer and adds to the morning emissions from traffic and from LPG transmission systems. Since LPG is used by Mexican households to heat water for bathing and showering prior to going to work in the morning, the emission of these alkanes is higher during this period of maximum LPG usage. After 09:00 h their ambient concentrations start to decrease as the CBL evolves and the photochemistry increases. The ethane levels decrease relatively less and slower than those of propane and butane because of its lower reactivity with the $\mathrm{OH}$ radical, and because it is emitted also by other sources, such as vehicle exhaust and degreasing activities (Vega et al., 2000).
Velasco et al. (2007) demonstrated that VOCs levels in Mexico City depend strongly on traffic emissions. Acetylene is known to be a good marker for vehicular combustion and therefore is a good indicator to analyze the traffic influence in the vertical and diurnal distribution of VOCs. The morning rush-hour period is clearly identified between 05:30 and 09:30 h, when acetylene concentrations are at least 3 times higher than those before and after this period, reaching above $50 \mathrm{ppbv}$ between 07:00 and 09:00 $\mathrm{h}$, when the traffic is the most intense. The same behavior was observed for other species emitted also by vehicle exhaust, such as propylene, pentane, hexane, heptane, octane, benzene, toluene and oxylene. However, there were a few exceptions, some profiles also showed high concentrations before or after the morning rush hours. These anomalous profiles may be due to emissions from other anthropogenic activities that only occur on specifics days. For example, o-xylene is emitted also during incineration of solid wastes; although it is not a common 
practice in the city, it could be the cause of some profiles with high concentration. In the same context, benzene, toluene and hexane are emitted also by the usage of solvents, paints, adhesives, resins and degreasers that are not necessarily used every day at the same hour and intensity. This type of emissions is common in Mexico City within the informal sector, such as workshops or small factories hidden in the urban canopy. Nonane is the only VOC that does not show a clear diurnal distribution. Nonane is emitted also by vehicle exhaust, but it shows high concentration throughout the day, which may be due to local plumes emitted by factories or other emissions sources close to the monitoring site.

3.6 Vertical profiles of $\mathrm{O}_{3}$, VOCs and meteorological parameters under different meteorological events

The irregular features observed in the vertical distributions of meteorological parameters and trace gases in Figs. 6 and 10 show the variability on the profiles due to particular meteorological conditions, random plumes or both. The random plumes are common in the emissions of an urban area like Mexico City, but the constant turbulence presence due to the intense thermal force produced by the urban energy balance tends to form rapidly uniform vertical profiles of trace gases within the CBL. The parcels with higher concentrations of VOCs in this layer were likely due to plumes emitted from emission sources close to the monitored site on specific days, as well as artifacts from our measurements, as mentioned before. Above the CBL, the vertical distribution of trace gases can be affected by the wind circulation in the Valley of Mexico; however no significant differences in the $\mathrm{O}_{3}$ and VOCs profiles were observed in the 1000 and 200-m layers above the ground, only differences in the concentrations were observed from one day to another. The surface ozone distribution in the Valley of Mexico relies on wind circulation, while the location and intensity of the ozone peaks depend on meteorological conditions. The VOCs distribution depends also on the location of the emission sources but to a lesser extent, since vehicle exhaust is the main source for many VOC species, and the traffic is a relatively homogeneous problem throughout the city.

To investigate the differences on the vertical profiles under different meteorological conditions, we used the classification of meteorological events in the Valley of Mexico defined by de Foy et al. (2005) during the MCMA-2003 field campaign. de Foy et al. (2005) identified 3 different meteorological episodes $-\mathrm{O}_{3}$-South, Cold Surge and $\mathrm{O}_{3}$-North - using a combination of synoptic and basin observations based on whether the day was predominantly cloudy, or whether the $\mathrm{O}_{3}$ peak occurred in the northern or southern part of the valley. The Cold Surge days are associated with "El Norte" events, with strong winds from the north bringing cold moist air and rain, and leading to stable conditions with high concentrations of primary pollutants and $\mathrm{O}_{3}$ peaks in the center of the city. The $\mathrm{O}_{3}$-North days occur when the sub-tropical jet is closer to the Valley of Mexico; they are characterized by strong westerly winds aloft and northerly winds in the basin during the morning, shifting to winds from the south and west during the day, and leading to $\mathrm{O}_{3}$ peaks in the north of the city. The wind circulation pattern on $\mathrm{O}_{3}$-South days is similar to $\mathrm{O}_{3}$-North days except in the afternoon, when the circulation shifts to southeasterly winds, leading to $\mathrm{O}_{3}$ peaks in the southeast of the city.

The tethered balloon was launched during 8 days of the MCMA-2003 campaign, 4 of those days corresponded to the Cold Surge event and the other 4 to the $\mathrm{O}_{3}$-North event. Figure 11 shows the vertical profiles of $\mathrm{O}_{3}, \theta$ and $q$, and Fig. 10 shows the profiles of 6 VOC species measured during these 8 days. During Cold Surge days the CBL evolved slower and reached lower elevations throughout the morning compared to $\mathrm{O}_{3}$-North days, as shown in the $\theta$ profiles. Besides of being slightly colder, the Cold Surge days presented higher humidity levels, with smaller negative $\Delta q$ as function of the elevation compared to $\mathrm{O}_{3}$-North days, in particular during the early morning and midmorning hours. Both types of episodes reached similar $\mathrm{O}_{3}$ peaks after midday at the CENICA site, but the ozone jump-start was observed one hour later during Cold Surge days. In addition, the slower evolution of the CBL enabled the ozone pool within the residual layer to remain longer during the morning, as shown in the $\mathrm{O}_{3}$ profiles in Fig. 11b. In regards to the VOCs profiles, no differences were observed between both meteorological events. On $\mathrm{O}_{3}$-North days higher evaporative emissions could be expected from a variety of sources, such as storage and distribution of gasoline in gas stations, because of the higher ambient temperature than on Cold Surge days $\left(\sim 5^{\circ} \mathrm{C}\right.$ difference during daytime); however, the difference in the temperature was too small to increase significantly the evaporative VOC emissions or to modify the vertical profiles. Also, although the lower temperature during Cold Surge days were expected to increase the emissions of light alkanes due to a higher LPG usage for water heating, but again the difference on the ambient temperature was not significant to produce differences in the vertical VOCs profiles, as shown in Fig. 10b for propane. No launches were made during $\mathrm{O}_{3}-$ South days. The diurnal patterns of the ambient parameters and $\mathrm{O}_{3}$ at ground level during $\mathrm{O}_{3}$-South days are similar to those on $\mathrm{O}_{3}$-North days; thus we presume that the evolution of the CBL and trace gases vertical distribution will be similar as well. The dry season is dominated by $\mathrm{O}_{3}$-North and $\mathrm{O}_{3}$-South events; thus $70 \%$ of the days corresponded to these two types of events during the MCMA-2003 field campaign. Consequently, the vertical diurnal distributions shown in Figs. 6 and 10 correspond more to the profiles from these two types of meteorological events. However, the evolution of the CBL and vertical distribution of trace gases in the low boundary layer of Mexico City do not change significantly from one type of event to another because the intense solar radiation and release of the stored heat in the urban surface are always sufficient to produce strong 

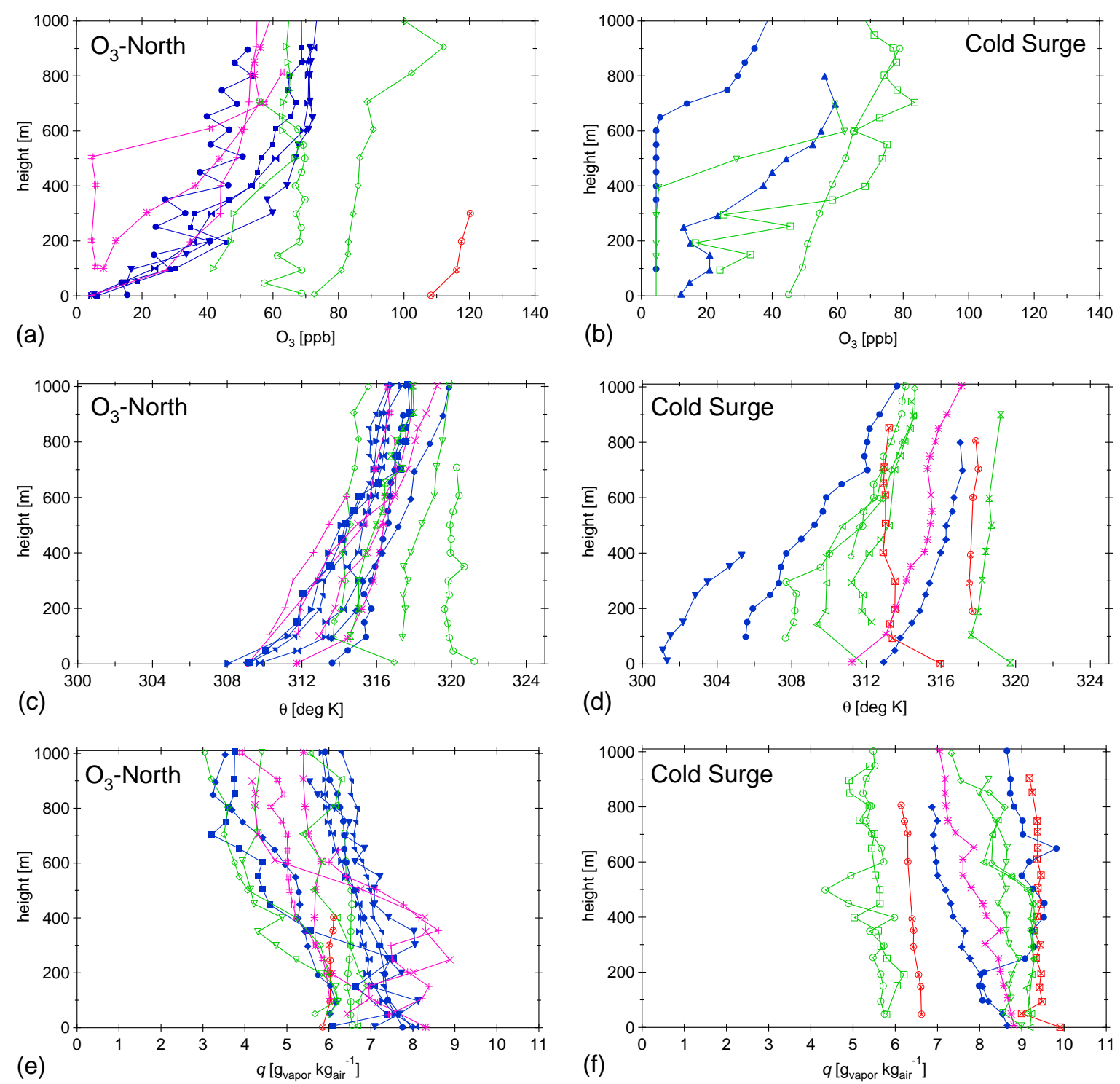

Fig. 11. Vertical profiles of $\mathrm{O}_{3}, \theta$ and $q$ measured on $\mathrm{O}_{3}$-North and Cold Surge days during the MCMA-2003 field campaign. Blue: before sunrise (before $6 \mathrm{~h}$ ); pink: morning ( 6 to $9 \mathrm{~h}$ ); green: late morning (9 to $12 \mathrm{~h}$ ); and red: afternoon.

turbulence and significant photochemical activity, including during Cold Surge events when the sky tends to be patchy from the clouds.

\section{Summary}

Strong inversion layers occur during nighttime and early hours in the morning in the atmosphere of Mexico City. The release of the heat stored in the urban surface is strong enough to maintain a 200-m unstable layer above the ground during nighttime. In this shallow layer, VOCs and other pollutants accumulate and append to the morning emissions that initiate the photochemical processes of the day. In contrast to VOCs, ozone is depleted within this layer by deposition and titration with NO from evening traffic emissions. But a fraction of the $\mathrm{O}_{3}$ from the previous day is carried over in the nocturnal stable layer, which forms a residual layer of $\mathrm{O}_{3}$ shielded from NO and VOCs emissions. The nocturnal stable layer starts at $200 \mathrm{~m}$, but a clear and well-established residual layer is observed at $500 \mathrm{~m}$. The average $\mathrm{O}_{3}$ concentration in the residual layer is $35 \mathrm{ppbv}$, although it frequently exceeds 50 ppbv.

After sunrise, the CBL evolves as the surface is heated and the nocturnal inversion is destroyed. This results in downward mixing $\mathrm{O}_{3}$ from aloft, which adds to the fresh $\mathrm{O}_{3}$ produced by the combination of high $\mathrm{OH}$ reactivity, abundant 
$\mathrm{NO}_{\mathrm{x}}$ and quite possibly, from high emissions of $\mathrm{CH}_{3} \mathrm{CHO}$ and $\mathrm{HCHO}$ in the presence of intense sunlight. However, the ground-level $\mathrm{O}_{3}$ concentration does not rise until 09:00 h, even though the $\mathrm{O}_{3}$ production rate is high. This period is characterized by an $\mathrm{O}_{3}$ balance determined by photochemical production, entrainment from the residual layer and destruction by titration with $\mathrm{NO}$, forming $\mathrm{NO}_{2}$ and then $\mathrm{HNO}_{3}$. Also during this period the high VOCs concentrations observed correspond to the intense traffic during the morning rush-hours.

A special feature of the CBL in Mexico City is its slow evolution during the morning hours compared to other places. By noon the CBL reaches a height below $600 \mathrm{~m}$, but grows rapidly to heights above $1000 \mathrm{~m}$ in the subsequent two hours. By this time the vertical distributions of $\mathrm{O}_{3}$, VOCs and moisture are uniform as a consequence of the vigorous vertical mixing within the $\mathrm{CBL}$. Around $14: 00 \mathrm{~h}, \mathrm{O}_{3}$ attains maximum values above $120 \mathrm{ppbv}$, coinciding with the period of strongest solar radiation. After the rapid growth stage of the CBL ending at 14:00 $\mathrm{h}$, a quenching stage follows in which the rates of heating and growth slow down during the next $2 \mathrm{~h}$. Then a rapid and deep cooling stage occurs with the decay of the boundary layer and the formation of a new nocturnal stable layer a few minutes before sunset. The $\mathrm{O}_{3}$ concentration begins to decrease when the sunlight diminishes in the afternoon. The strong afternoon winds enhance the pollutants dispersion, contributing to the $\mathrm{O}_{3}$ reduction within the boundary layer.

\section{Conclusions}

The vertical distribution of $\mathrm{O}_{3}$ and 13 VOCs in the low boundary layer of Mexico City was investigated using a tethered balloon during 2000-2004 to better understand the complex interactions between these pollutants and different meteorological variables, as well as their influence on air quality. Tethered balloons offer a direct way of probing into the urban atmosphere. Of particular interest are the micrometeorological variables, such as turbulence and atmospheric stability, on which the vertical distribution of pollutants depends strongly. These parameters and vertical distributions of trace gases need to be reproduced by air quality models to reduce the discrepancies between measured and modeled concentrations of $\mathrm{O}_{3}$ and other secondary pollutants in the atmosphere of Mexico City.

Future studies should extend the number of chemical species measured, such as $\mathrm{NO}_{\mathrm{x}}, \mathrm{CO}$ and a larger number of VOC species, as well as the altitude at which the samples are collected. Vertical profiles of $\mathrm{NO}$ and $\mathrm{NO}_{2}$ will provide valuable information to understand better the photochemical processes; different $\mathrm{NO}$ and $\mathrm{NO}_{2}$ sensors have been used successfully in tethered balloons (Pisano et al., 1997; Glaser et al., 2003). The Teflon tubing used in this study is limited in height by its own weight; alternative options to collect samples at higher altitudes include active charcoal cartridges (Glaser et al., 2003; Greenberg et al., 1999) and Teflon bags with small time-controlled pumps and immediate analysis of the samples (Chen et al., 2002). These alternative sensors and sampling systems will allow also investigate further the interferences on the $\mathrm{O}_{3}$ electrochemical cells caused by other oxidant species at different heights within severely polluted atmospheres, in particular at nighttime when the profiles are not uniform.

Acknowledgements. JICA supported this study from 2000 to 2002. In 2002 and 2003 the study was supported by the Metropolitan Commission of Environment (CAM) from Mexico City as part of the MCMA-2002 \& 2003 field campaigns. The 2004 measurements were supported by CONACY-SEMARNAT. MIT/MCE2 has been supported by the CAM, the US Department of Energy (DOE DE-FG02-05ER63980) and the National Science Foundation (ATM-0528227 and ATM-0511803) for the data analysis. The logistical support provided by the Mexican Aeronautical Authorities was fundamental for the satisfactory development of this study. The $\mathrm{O}_{3}$ and benzene data at ground level was provided by R. Volkamer from University of Colorado. The butane data at ground level was provided by J. Samuelsson and J. Mellqvist from Chalmers University of Technology. The energy balance and olefin data at ground level was provided by B. Lamb from Washington State University. The support provided by V. Gutierrez-Avedoy, M. Ito, I. Gamo, K. Ishii, T. Igarashi for the development of this study and the technical assistance from E. Segovia, L. Gonzalez, F. Angeles, F. Mandujano, A. Garcia-Gutierrez, S. Hernandez, and others at CENICA are gratefully acknowledged. Finally, the authors acknowledge the constructive comments from the two reviewers and the editor, which helped in improving this article.

Edited by: C. E. Kolb

\section{References}

Aneja, V. P., Mathur, R., Arya, S. P., Li, Y., Murray, G. C., and Manuszak, T. L.: Coupling the vertical distribution of ozone in the atmospheric boundary layer, Environ. Sci. Technol., 34, 2324-2329, 2000.

Arya, S. P.: Introduction to micrometeorology, Academic Press, Great Britain, 2001.

Barnes, R. A., Bandy, A. R., and Torres, A. L.: Electrochemical concentration cell ozonosonde accuracy and precision, J. Geophys. Res., 90, 7881-7887, 1985.

Baumbach, G. and Vogt, U.: Influence of inversion layers on the distribution of air pollutants in urban areas, Water, Air, and Soils Pollution: Focus, 3, 65-76, 2003.

Chen, C. L., Tsuang, B. J., Tu, C. Y., Cheng, W. L., and Lin, M. D.: Wintertime vertical profiles of air pollutants over a suburban area in central Taiwan, Atmos. Environ., 36, 2049-2059, 2002.

de Foy, B., Varela, J. R., Molina, L. T., and Molina, M. J.: Rapid ventilation of the Mexico City basin and regional fate of the urban plume, Atmos. Chem. Phys., 6, 2321-2335, 2006, http://www.atmos-chem-phys.net/6/2321/2006/.

de Foy, B., Caetano, E., Magaña, V., Zitacuaro, A., Cardenas, B., Retama, A., Ramos, R, Molina, L. T., and Molina, M. J.: Mexico 
City basin wind circulation during the MCMA-2003 field campaign, Atmos. Chem. Phys., 5, 2267-2288, 2005, http://www.atmos-chem-phys.net/5/2267/2005/.

DKK Corporation: Instruction manual. Automatic analyzer for atmospheric hydrocarbons GAS-3051A, Manual No. GAS-01700. DKK Corporation, Tokyo, Japan, 1998.

Doran, J. C., Abbott, S., Archuleta, J., Bian, X., Chow, J., et al.: The IMADA-AVER boundary layer experiment in the Mexico City area, B. Am. Meteorol. Soc., 79, 2497-2508, 1998.

Doran, J. C., Berkowitz, C. M., Coulter, R. L., Shaw, W., and Spicer, C. W.: The 2001 Phoenix Sunrise experiment: vertical mixing and chemistry during the morning transition in Phoenix, Atmos. Environ., 37, 2365-2377, 2003.

Galbally, I.: Some measurements of ozone variation and destruction in the atmospheric surface layer, Nature, 218, 456-457, 1968.

Garcia, A. R., Volkamer, R., Molina, L. T., Molina, M. J., Samuelson, J., Mellqvist, J., Galle, B., Herndon, S. C., and Kolb, C. E.: Separation of emitted and photochemical formaldehyde in Mexico City using a statistical analysis and a new pair of gas-phase tracers, Atmos. Chem. Phys., 6, 4545-4557, 2006,

http://www.atmos-chem-phys.net/6/4545/2006/.

Glaser, K., Vogt, U., Baumbach, G., Voz-Thomas, A., and Geiss, H.: Vertical profiles of $\mathrm{O}_{3}, \mathrm{NO}_{2}, \mathrm{NO}_{\mathrm{x}}, \mathrm{VOC}$, and meteorological parameters during the Berlin Ozone Experiment (BERLIOZ) campaign, J. Geophys. Res., 108(D4), 8253, doi:10.1029/2002JD002475, 2003.

Grant, R. H. and Wong, K. L.: Ozone profiles over a suburban neighborhood, Atmos. Environ., 33, 51-63, 1999.

Greenberg, J. P., Guenther, A., Zimmerman, P., Baugh, W., Geron, C., Davis, K., Helmig, D., and Klinger, L. F.: Tethered balloon measurements of biogenic VOCs in the atmospheric boundary layer, Atmos. Environ., 33, 855-867, 1999.

Guenther, A. and Hills, A.: Eddy covariance measurement of isoprene fluxes, J. Geophys. Res., 103, 13 145-13 152, 1998.

Lee, S. M., Fernando, H. J .S., Princevac, M., Zajic, D., Sinesi, M., Mcculley, J. L., and Anderson, J.: Transport and diffusion of ozone in the nocturnal and morning planetary boundary layer of the Phoenix Valley, Environ. Fluid Mech., 3, 331-362, 2003.

Lei, W., de Foy, B., Zavala, M., Volkamer, R., and Molina, L. T.: Characterizing ozone production in the Mexico City Metropolitan Area: a case study using a chemical transport model, Atmos. Chem. Phys., 7, 1347-1366, 2007,

http://www.atmos-chem-phys.net/7/1347/2007/.

Molina, L. T., Kolb, C. E., de Foy, B., Lamb B. K., Brune, W. H., Jiménez, J. L., Ramos-Villegas, R., Sarmiento, J., ParamoFigueroa, V. H., Cardenas, B., Gutierrez-Avedoy, V., and Molina, M. J.: Air quality in North America's most populous city overview of the MCMA-2003 campaign, Atmos. Chem. Phys., 7, 2447-2473, 2007, http://www.atmos-chem-phys.net/7/2447/2007/.

Molina, L. T. and Molina, M. J. (Eds.): Cleaning the air: a comparative study, in: Air Quality in the Mexico Megacity. An integrated assessment, Kluwer Academic Publishers, Netherlands, 2002.

Nickerson, C. E., Sosa, G., Hochstein, H., McCaslin, P., Luke, W., and Schanot, A.: Measurements of Mexico City air pollution by a research aircraft, Atmos. Environ., 26B, 445-451, 1992.

Parrish, D. D. and Fehsenfeld, F. C.: Methods for gas-phase measurements of ozone, ozone precursors and aerosol precursors, Atmos. Environ., 34, 1921-1957, 2000.
Pérez-Vidal, H. and Raga, G. B.: On vertical distribution of pollutants in Mexico City, Atmosfera, 11, 95-108, 1998.

Pisano, J. T., Mckendry, I., Steyn, D. G., and Hastie, D. R.: Vertical nitrogen dioxide and ozone concentrations measured from a tethered balloon in the lower Fraser Valley, Atmos. Environ., 31, 2071-2078, 1997.

Salcedo, D., Onasch, T. B., Dzepina, K., Canagaratna, M. R., Zhang, Q., Huffman, J. A., DeCarlo, P. F., Jayne, J. T., Mortimer, P., Worsnop, D. R., Kolb, C. E., Johnson, K. S., Zuberi, B., Marr, L. C., Volkamer, R., Molina, L. T., Molina, M. J., Cardenas, B., Bernabé, R. M., Márquez, C., Gaffney, J. S., Marley, N. A., Laskin, A., Shutthanandan, V., Xie, Y., Brune, W., Lesher, R., Shirley, T., and Jimenez, J. L.: Characterization of ambient aerosols in Mexico City during the MCMA-2003 campaign with Aerosol Mass Spectrometry: results from the CENICA Supersite, Atmos. Chem. Phys., 6, 925-946, 2006, http://www.atmos-chem-phys.net/6/925/2006/.

Schifter, I., Diaz, L., Lopez-Salina, E., Rodriguez, R., Avalos, S., and Guerrero, V.: An evaluation of the LPG vehicles program in the Metroploitan Area of Mexico City, J. Air Waste Manage. Assoc., 50, 301-309, 2000.

Shirley, T. R., Brune, W. H., Ren, X., Mao, J., Cardenas, B., Volkamer, R., Molina, L. T., Molina, M. J., Lamb, B., Velasco, E., Jobson, T., and Alexander, M.: Atmospheric oxidation in the Mexico City Metropolitan Area (MCMA) during April 2003, Atmos. Chem. Phys. 6, 2753-2765, 2006.

Streit, G. E. and Guzmán, F.: Mexico City air quality: Progress of an international collaborative project to define air quality management options, Atmos. Environ., 30, 723-733, 1996.

Stull, R. B.: An Introduction to Boundary Layer Meteorology, Kluwer Academic Publishers, Netherlands, 1988.

Vega, E., Mugica, V., Carmona, R., and Valencia, E.: Hydrocarbon source apportionment in Mexico City using the chemical mass balance receptor model, Atmos. Environ, 34, 4121-4129, 2000.

Volkamer, R., Molina, L. T., Molina, M. J., Shirley, T., and Brune, W. H.: DOAS measurement of glyoxal as an indicator for fast VOC chemistry in urban air, Geophys. Res. Lett., 32, L08806, doi:10.1029/2005GL022616, 2005.

Volkamer, R., Sheehy, P. M., Molina, L. T., and Molina, M. J.: Oxidative capacity of the Mexico City atmosphere - Part 1: A radical source perspective, Atmos. Chem. Phys. Discuss., 7, 53655412, 2007, http://www.atmos-chem-phys-discuss.net/7/5365/2007/.

Velasco, E., Pressley, S., Allwine, E., Westberg, H., and Lamb, B., 2005. Measurements of $\mathrm{CO}_{2}$ fluxes from the Mexico City urban landscape, Atmos. Environ. 39, 7433-7446, 2005.

Velasco, E., Lamb, B., Westeberg, H., Allwine, E., Sosa, G., Arriaga-Colina, J. L., Jonson, B. T., Alexander, M. L., Prazeller, P., Knighton, W. B., Rogers, T. M., Grutter, M., Herndon, S. C., Kolb, C. E., Zavala, M., de Foy, B., Volkamer, R., Molina, L. T., and Molina, M. J.: Distribution, magnitudes, reactivities, ratios and diurnal patterns of volatile organic compounds in the Valley of Mexico during the MCMA 2002 \& 2003 field campaigns, Atmos. Chem. Phys., 7, 329-353, 2007, http://www.atmos-chem-phys.net/7/329/2007/.

Whiteman, C. D., Zhong, S., Bian, X., Fast, J. D., and Doran, J. C.: Boundary layer evolution and regional-scale diurnal circulations over the Mexico Basin and Mexican plateau, J. Geophys. Res., 105, 10081-10 102, 2000. 
Wöhrnschimmel, H., Márquez, C., Mugica, V., Stahel, W. A., Staehelin, J., Cárdenas, B., and Blanco, S.: Vertical profiles and receptor modeling of volatile organic compounds over Southeastern Mexico City, Atmos. Environ, 40, 5125-5136, 2006.

Zavala, M., Herndon, S. C., Slott, R. S., Dunlea, E. J., Marr, L. C., Shorter, J. H., Zahniser, M., Knighton, W. B., Rogers, T. M., Kolb, C. E., Molina, L. T., and Molina, M. J.: Characterization of on-road vehicle emissions in the Mexico City Metropolitan Area using a mobile laboratory in chase and fleet average measurement modes during the MCMA-2003 field campaign, Atmos. Chem. Phys., 6, 5129-5142, 2006,

http://www.atmos-chem-phys.net/6/5129/2006/. 